\title{
Microglial Cell Morphology and Phagocytic Activity Are Critically Regulated by the Neurosteroid Allopregnanolone: A Possible Role in Neuroprotection
}

\author{
Valérie Jolivel (D), Susana Brun, Fabien Binamé, Jérémie Benyounes, Omar Taleb (), Dominique Bagnard (D), \\ Jérôme De Sèze, Christine Patte-Mensah and Ayikoe-Guy Mensah-Nyagan *(i)
}

\section{check for} updates

Citation: Jolivel, V.; Brun, S.; Binamé, F.; Benyounes, J.; Taleb, O.; Bagnard, D.; De Sèze, J.; Patte-Mensah, C.; Mensah-Nyagan, A.-G. Microglial Cell Morphology and Phagocytic Activity Are Critically Regulated by the Neurosteroid Allopregnanolone: A Possible Role in Neuroprotection. Cells 2021, 10, 698. https://doi.org/ 10.3390/cells10030698

Academic Editor: Hakan Aldskogius

Received: 19 January 2021

Accepted: 17 March 2021

Published: 21 March 2021

Publisher's Note: MDPI stays neutral with regard to jurisdictional claims in published maps and institutional affiliations.

Copyright: (c) 2021 by the authors. Licensee MDPI, Basel, Switzerland. This article is an open access article distributed under the terms and conditions of the Creative Commons Attribution (CC BY) license (https:// creativecommons.org/licenses/by/ $4.0 /)$.
Biopathologie de la Myéline, Neuroprotection et Stratégies Thérapeutiques, INSERM U1119, Centre de Recherche en Biomédecine de Strasbourg (CRBS), Fédération de Médecine Translationnelle de Strasbourg (FMTS), Université de Strasbourg, 1 rue Eugène Boeckel, 67000 Strasbourg, France; vjolivel@unistra.fr (V.J.); susana.brun@unistra.fr (S.B.); biname@unistra.fr (F.B.); jbenyounes@unistra.fr (J.B.);omar@unistra.fr (O.T.); bagnard@unistra.fr (D.B.); jerome.de.seze@chru-strasbourg.fr (J.D.S.); cmensah@unistra.fr (C.P.-M.)

* Correspondence: gmensah@unistra.fr

\begin{abstract}
Microglial cells are key players in neural pathogenesis and microglial function regulation appears to be pivotal in controlling neuroinflammatory/neurological diseases. Here, we investigated the effects and mechanism of action of neurosteroid allopregnanolone (ALLO) on murine microglial BV-2 cells and primary microglia in order to determine ALLO-induced immunomodulatory potential and to provide new insights for the development of both natural and safe neuroprotective strategies targeting microglia. Indeed, ALLO-treatment is increasingly suggested as beneficial in various models of neurological disorders but the underlying mechanisms have not been elucidated. Therefore, the microglial cells were cultured with various serum concentrations to mimic the blood-brainbarrier rupture and to induce their activation. Proliferation, viability, RT-qPCR, phagocytosis, and morphology analyzes, as well as migration with time-lapse imaging and quantitative morphodynamic methods, were combined to investigate ALLO actions on microglia. BV-2 cells express subunits of GABA-A receptor that mediates ALLO activity. ALLO $(10 \mu \mathrm{M})$ induced microglial cell process extension and decreased migratory capacity. Interestingly, ALLO modulated the phagocytic activity of BV-2 cells and primary microglia. Our results, which show a direct effect of ALLO on microglial morphology and phagocytic function, suggest that the natural neurosteroid-based approach may contribute to developing effective strategies against neurological disorders that are evoked by microglia-related abnormalities.
\end{abstract}

Keywords: microglia; neurosteroid; allopregnanolone; GABA-A receptor; oligodendrocyte; multiple sclerosis

\section{Introduction}

Microglia represent the resident macrophages of the central nervous system (CNS) [1]. They are derived from erythromyeloid progenitors that are found in the yolk bag and they are maintained throughout life without the contribution of adult hematopoiesis [2]. Under physiological conditions, microglia are distributed throughout the whole CNS, where they perform tasks that are essential to development and homeostasis. Their thin and ramified processes are continuously scanning the environment $[3,4]$. Upon detection of an activating stimulus in the surrounding environment, microglia rapidly change their morphology, may adopt an inflammatory or an anti-inflammatory polarization, and actively perform debris phagocytosis [2].

Multiple sclerosis (MS) is a major neurological disorder involving microglia. MS is an autoimmune disease that leads to demyelination of the CNS. MS represents the most common non-traumatic neurological disorder in young patients. It is characterized by 
the presence of focal demyelinating lesions that exhibit variable degrees of inflammation, reactive gliosis, and neurodegeneration [5]. A hallmark of this pathology is the presence of myelin-laden phagocytes [6]. In normal-appearing white matter of MS patients, clusters of reactive microglia are found in the absence of leukocyte infiltration and demyelination [7]. These nodules, expressing high levels of pro-inflammatory genes and considered as 'preactive lesions', may eventually develop into active demyelinating MS lesions [8]. A similar observation has been done in experimental autoimmune encephalomyelitis (EAE), a commonly used animal model of MS. At early stages of the disease, i.e., before paralysis onset, microglia form perivascular nodules triggered by fibrinogen leakage [9]. Interestingly, focal rupture of the blood-brain barrier (BBB) also occurs in patients with progressive MS [10]. The exposure of microglia to serum leads to functional and transcriptomic modifications. In particular, they adopt a round amoeboid shape, a representative morphology of activated microglia, and they increase their phagocytic activity [11]. These data suggest that early BBB permeabilization may trigger microglia activation upstream formation of new lesions in MS.

Recently, a large body of proof has highlighted the important cross-talk occurring between the nervous and immune systems. Intriguingly, neural and immune cells share components of the neurotransmitters pathways. Accordingly, immune cells, such as lymphocytes, dendritic cells, or macrophages, express the metabolic machinery for $\gamma$ aminobutyric acid (GABA), the principal inhibitory neurotransmitter in the adult CNS [12]. This immune GABA signaling system is active and it can modulate various functions, like cytokine secretion, cell proliferation, phagocytic activity, and chemotaxis [12]. Human and mouse microglia, as well as the murine microglial BV-2 cell line, express GABA-A receptors that modulate microglial functions, such as motility and volume sampling $[4,13,14]$. Moreover, GABA seems to be implicated in autoimmune diseases, like multiple sclerosis [15]. Indeed, the oral administration of agents increasing GABA concentrations delays the onset of paralysis in an EAE model via the inhibition of inflammation [16]. GABA can exert its activity via two classes of receptors: the ionotropic GABA-A receptors and the metabotropic GABA-B receptors, both being expressed by microglia [17,18]. Numerous modulators of the GABA-A receptors have been described, among them the class of neuroactive steroids [19]. Interestingly, a disturbance of neurosteroid synthesis has been reported in the CNS of MS patients, as well as in an EAE model [20-22]. In the work of Noorbakhsh et al., measurements by gas chromatography-mass spectrometry revealed reduced levels of dehydroepiandrosterone and ALLO in the brain of MS patients [20]. Interestingly, the administration of ALLO to mice after EAE induction limited the development of the pathology. Besides MS, the neuroprotective activity of ALLO has been shown in many animal models of neurological diseases. such as Niemann-Pick disease [23], Alzheimer's disease [24], Parkinson's disease [25], peripheral neuropathies [26-29], or brain ischemia [30]. In vitro, ALLO exhibited a direct antiapoptotic activity on neurons [31] via a reduction of the release of cytochrome $\mathrm{c}$, the inhibition of Bax translocation, and DNA fragmentation [32]. This neuroprotective effect induced the transcription of GABA-A receptor subunits [33]. The beneficial activity of ALLO is also mediated by a reduced production of reactive oxygen species (ROS) [34]. Besides the direct antiapoptotic effect exerted by ALLO on neurons, the immunomodulatory activities of this neurosteroid, especially on microglia, are poorly known.

The interactions that were observed between neurotransmitters and the immune system represent new prospects for understanding neuroinflammation $[35,36]$. Targeting microglia would represent a potential new therapeutic strategy for neurological diseases. In this context, we analyzed the effect of ALLO on microglial functions in physiological and pathological conditions. We found that this neurosteroid induces the elongation of the processes that are borne by microglia and modulates their migration, as well as their phagocytic capacity. 


\section{Materials and Methods}

\subsection{Cell Culture and Treatment}

The murine microglial BV-2 cell line (that was kindly provided by Prof. H. Luhmann, University of Mainz, Germany) and the murine oligodendroglial 158N cell line (generated in the laboratory) were cultured in DMEM with GlutaMAX (Gibco, Bazel, Switzerland), $4.5 \mathrm{mg} / \mathrm{mL}$ glucose, which was supplemented with $50 \mathrm{U} / \mathrm{mL}$ penicillin (Gibco), $50 \mu \mathrm{g} / \mathrm{mL}$ streptomycin (Gibco) and 10\% (for BV-2) or 5\% (for 158N) heat-inactivated Fetal Calf Serum (FCS, Gibco). The cells were subcultured twice a week after their detachment and dissociation with the Cell Dissociation Solution Non-enzymatic 1x (Sigma, Saint-Quentin, France). Primary murine microglia were isolated from C57BL/6J mouse pups. In brief, the brains were harvested from postnatal day 1-4 mice. The cortices were dissected from the forebrain, and the surrounding meninges were removed. Intact cortices were mechanically and enzymatically dissociated while using trypsin. The reaction was stopped by the addition of trypsin inhibitor. Mixed glial cultures were established in DMEM/F12 with GlutaMAX, which was supplemented with 10\% FCS and penicillin/streptomycin. After 2 weeks, microglia were isolated and re-plated. Culture purity was assessed by microscopy or flow cytometry after staining with antibodies that were directed against Iba-1, or CD45 and CD11b respectively. Murine peritoneal macrophages were obtained from adult C57BL/6J by peritoneal lavage with $5 \mathrm{~mL}$ ice-cold PBS. The cells were plated in RPMI 1640 supplemented with 10\% FCS and penicillin/streptomycin. The macrophages were subsequently purified by adherence to tissue culture plastic. All of the cells were grown at $37^{\circ} \mathrm{C}$ in a humidified incubator with $5 \% \mathrm{CO}$. To treat the cells, stock solutions of ALLO (Sequoia Research Product Ltd., United Kingdom) were prepared with DMSO.

To mimic BBB disruption leading to microglial activation, BV-2 cells and primary murine microglia were cultured in the presence of $10 \%$ FCS, whereas more quiescent cells were obtained thanks to incubation with $1 \%$ FCS.

\subsection{Evaluation of Cell Viability}

Cell survival is evaluated by either flow cytometry or MTT assay. For the cytometric determination, the BV-2 cells were plated in triplicate into 24 -well plates $\left(3 \times 10^{5}\right.$ cells $\left./ \mathrm{mL}\right)$ and then incubated with graded concentrations of ALLO comprised between 0 and $10 \mu \mathrm{M}$ in presence of $1 \%$ or $10 \%$ FCS. Both floating and adherent cells were pooled in a hemolysis tube, centrifuged, and then resuspended into $300 \mu \mathrm{L}$ PBS. Prior to the cytometric analysis, $1 \mu \mathrm{L}$ of 7-AAD (BioLegend, London, United Kingdom) was added to the cell suspension. The acquisition was realized with the BD Accuri C6 Plus flow cytometer (BD Biosciences, Le Pont de Claix, France). After exclusion of debris and doublets, the percentage of living cells (7-AAD negative cells) was measured. For the MTT assay, BV-2 and $158 \mathrm{~N}$ cells were seeded at $3 \times 10^{3}$ cells per well into 96-well plates and then incubated with graded concentrations of ALLO comprised between 0 and $50 \mu \mathrm{M}$ in presence of $1 \%$ or $10 \%$ FCS. The MTT (Sigma) was added to a final concentration of $0.5 \mathrm{mg} / \mathrm{mL}$ to each well and then allowed to incubate in the dark at $37^{\circ} \mathrm{C}$ for $2 \mathrm{~h}$ to obtainpurple colored formazan products. Afterwards, the medium was removed and the formazan crystals were dissolved with $200 \mu \mathrm{L}$ DMSO. Spectrophotometric measurements were performed at $570 \mathrm{~nm}$ to determine the cell viability (Multiskan Go, Thermo Scientific, Villebon sur Yvette, France).

In order to evaluate the deleterious activity of BV-2, the culture medium of $158 \mathrm{~N}$ seeded in 24-well plates was replaced by supernatants isolated after $24 \mathrm{~h}$ of contact with BV-2 cells. One day later, the viability of $158 \mathrm{~N}$ cells was measured by flow cytometry following a staining with 7-AAD.

\subsection{Analysis of Apoptotic and Necrotic Cell Death}

After incubation with ALLO or vehicle, the BV-2 cells were detached and stained with annexin V coupled to PE and propidium iodide (PI), according to the manufacturer's protocol (Invitrogen, Saint Aubin, France). The activation of caspase-3 was also investigated 
with the 'PE Active Caspase-3 Apoptosis Kit' (BD Biosciences). The cells were subsequently analyzed by flow cytometry to distinguish the different stages of cell death.

\subsection{Analysis of Cell Proliferation}

BV-2 and $158 \mathrm{~N}$ cells were labeled with $5 \mu \mathrm{M}$ of the cell tracer Carboxyfluorescein Diacetate Succinimidyl Ester (CFSE, eBioscience, San Diego, CA, USA) and then cultured in triplicate in 24-well plates. The next day, they were treated with graded concentrations of ALLO or vehicle. After 3-4 days of culture, the cells were detached and washed with PBS. They were subsequently analyzed by flow cytometry. After the exclusion of debris, the gate was applied on the live cell population, the doublets were removed, and the dilution of CFSE was determined.

\subsection{Phagocytosis Assay}

BV-2 cells, primary microglia, Raw264.7, or peritoneal macrophages were seeded in 24-well plates. Twenty-four hours after treatment with graded concentrations of ALLO or vehicle, the cells were incubated with FITC-dextran $70 \mathrm{kDa}$ (Sigma, final concentration: $1 \mathrm{mg} / \mathrm{mL}$ ) during 2 hat $37^{\circ} \mathrm{C}$. The negative control cells were incubated on ice. BV-2 cells were alternatively incubated with 1- $\mu$ m latex beads coupled to FITC (Sigma). The internalization of FITC-dextran or FITC-latex beads was measured by flow cytometry after detachment and extensive washing of the cells. A double staining with anti-CD11b was performed to assess microglia or macrophage purity.

\subsection{BV-2 and $158 \mathrm{~N}$ Cell Line Co-Culture}

$158 \mathrm{~N}$ cells were stained with CFSE and plated into 24-well plates $\left(75 \times 10^{3}\right.$ cells $\left./ \mathrm{mL}\right)$. BV-2 cells stably expressing tdTomato have been generated with a lentiviral construct. Twenty-four hours after a treatment with ALLO or vehicle, BV-2 tomato cells grown in the presence of $10 \%$ FCS were detached, washed, and suspended in $158 \mathrm{~N}$ dedicated culture medium. BV-2 cells $\left(50 \times 10^{3}\right.$ cells/well) were added on the top of CFSE- $158 \mathrm{~N}$ cells. After 24-h co-culture, the cells were analyzed by flow cytometry to count the BV-2 cells having phagocytized $158 \mathrm{~N}$ cells or fixed for microscopic observation.

\subsection{Morphological Analysis of BV-2 Cells}

The BV-2 cells were seeded in $35 \mathrm{~mm}$-Petri dishes. Twenty-four hours after treatment with ALLO or vehicle, the microphotographies were realized using the microscope Eclipse TS100 (Nikon, Champigny sur Marne, France) that was equipped with the DS-FI1 camera (Nikon) with the $\times 10$ or the $\times 40$ objective. The number of primary processes, i.e., those that emerge from the cell body, allows for distinguishing between bipolar and multipolar microglia. Bipolar cells exhibit two primary processes and multipolar cells more than three processes. The total length of each process, from the emergence point to the further extremity, was manually measured using ImageJ.

\subsection{Morphological Analysis of Primary Microglial Cells}

The primary microglial cells were seeded in Lab-TekTM chamber slides (Thermo Scientific Nunc). Twenty-four hours after treatment with ALLO or vehicle, the cells were fixed in $2 \%$ paraformaldehyde and subsequently immunostained with a primary antibody against Iba-1 (Wako, Osaka, Japan), followed by a secondary antibody coupled to AlexaFluor 488 (Abcam, Paris, France). The nuclei were counterstained with DAPI. Microphotographies were realized using the microscope IX73 (Olympus, Rungis, France) with the $\times 20$ objective. The total cell length of bipolar Iba-1 positive cells was manually measured using ImageJ.

\subsection{Time-Lapse Imaging and Quantitative Morphodynamics Analysis of BV-2 Cells}

The BV-2 cells were seeded in $60 \mathrm{~mm}$-Petri dishes at the density of $3 \times 10^{5}$ cells $/ \mathrm{mL}$ and then treated with $10 \mu \mathrm{M}$ ALLO or the vehicle (DMSO). The next day, time-lapse imaging was acquired using the microscope Axiovert 200M (Zeiss, Jena, Germany) with 
the $\times 10$ objective. The system was equipped with the software MetaView. The cells were imaged during $2 \mathrm{~h}$ and a brightfield picture was taken every $2 \mathrm{~min}$. The analysis of the movement that was done by the nuclei was performed using the plugin MTrackJ available by ImageJ [35]. The total path traveled by the cells (= path length) during the experiment and the distance between the start and the end point (= D2S) were measured.

\subsection{Reverse Transcription and Real-Time Quantitative PCR}

The NucleoZOL reagent (Macherey-Nagel, Hoerdt, France) was used according to the manufacturer's instructions for the extraction of total RNA from BV-2 cells that were grown either in the presence of $1 \%$ or $10 \%$ FCS. Reverse transcription was performed with $1 \mu \mathrm{g}$ RNA using the iScript ${ }^{\mathrm{TM}}$ cDNA synthesis kit (Bio-Rad, Hercules, CA, USA). The quantitative PCR was performed with a CFX96 PCR detection system (Bio-Rad) using Bio-Rad SYBRGreen ${ }^{\circledR}$ dye. In order to calculate starting quantities, standard curve based on successive cDNA dilutions was set up by using the iCycleriQ optical system software (CFX manager Maestro Bio-Rad). Starting quantities of genes of interest were reported to those of the peptidylprolyl isomerase A (Ppia, cyclophilin A), phosphoglycerate kinase 1 (Pgk1) and hydroxymethylbilane synthase (Hmbs) genes used as reference genes. All of the samples were analyzed in triplicate. The specificity of the amplification was controlled by a melting curve ranging from $62^{\circ} \mathrm{C}$ to $95^{\circ} \mathrm{C}$ and allowing for the identification of a single peak that corresponds to the amplicon. Table 1 provides the primer sequences used for this study. The primer sequences for Hmbs were designed by Bio-Rad (Assay ID: qMmuCID0022816).

Table 1. Sequences of the oligonucleotides used for real-time PCR amplification.

\begin{tabular}{|c|c|c|c|}
\hline mRNA Target (Gene Name) & Forward Primer $\left(5^{\prime}-3^{\prime}\right)$ & Reverse Primer $\left(3^{\prime}-5^{\prime}\right)$ & Amplicon (bp) \\
\hline \multicolumn{4}{|l|}{ GABA-A R subunits } \\
\hline$\alpha 1($ GabrA1) & AAAAGCGTGGTTCCAGAAAA & GCTGGTTGCTGTAGGAGCAT & 84 \\
\hline$\alpha 2$ (GabrA2) & GCTACGCTTACACAACCTCAGA & GACTGGCCCAGCAAATCATACT & 115 \\
\hline ß3 (GabrB3) & GGGACCCCCGAAGTCGGGTCT & GAGCGTAAACGACCCCGGGAA & 100 \\
\hline$\delta(\mathrm{GabrD})$ & TCAAATCGGCTGGCCAGTTCCC & GCACGGCTGCCTGGCTAATCC & 145 \\
\hline \multicolumn{4}{|l|}{ Reference genes } \\
\hline $\begin{array}{l}\text { Glyceraldehyde-3-phosphate } \\
\text { dehydrogenase (Gapdh) }\end{array}$ & AGGTCGGTGTGAACGGATTTG & TGTAGACCATGTAGTTGAGGTCA & 123 \\
\hline $\begin{array}{c}\text { Peptidylprolyl isomerase A } \\
\text { (Ppia) }\end{array}$ & AGGGTTCCTCСTTTCACAGAATT & TGCCATTATGGCGTGTAAAGTC & 72 \\
\hline $\begin{array}{l}\text { Phosphoglycerate kinase } 1 \\
\text { (Pgk1) }\end{array}$ & ATTCTGCTTGGACAATGGAGC & AGGCATGGGAACACCATCA & 76 \\
\hline
\end{tabular}

Bp, base pair.

\subsection{Statistical Analysis}

Statistical analysis was performed using GraphPad Prism. The data are presented as mean \pm SEM from at least three independent experiments. Statistical analysis of the data was conducted using a non-parametric test (Mann-Whitney or Kruskal-Wallis tests), followed by a Dunn's multiple comparison test. Statistical analysis of the data from migration studies was realized using a parametric test (unpaired $t$-test).

\section{Results}

\subsection{Serum Represents an Activation Factor for the BV-2 Cell Line}

Serum is not found within the parenchyma of a healthy CNS. In pathological conditions, the rupture of the BBB allows the passage of large quantities of blood components. The exposure of microglia to serum leads to functional and transcriptomic modifications [11]. Therefore, serum represents an activation factor that we use in our experiments to mimic BBB disruptions. Here, we report the effect of decreasing concentrations of fetal calf serum (FCS) on cell survival, proliferation, morphology, and level of activation of the 
murine microglial cell line, BV-2. The exposure of BV-2 cells to reduced FCS concentrations is associated withan important loss of the cell viability determined by an MTT assay (Figure 1A) and corroborated by a 7-AAD staining, a dead cell exclusion dye (Figure 1B). Indeed, in comparison to BV-2 cells that are grown with 10\% FCS, the MTT signal is decreased by $62.2 \%$ when the cells are with $2 \%$ FCS, by $74.3 \%$ with $1 \%$ FCS, and by $90.2 \%$ when the cells are grown in the absence of FCS. In a similar way, we quantified $90.9 \%$ of living cells (i.e., 7-AAD negative) in presence of $10 \%$ FCS, $58.1 \%$ with $2 \%$ FCS, $49.4 \%$ with $1 \%$ and only $27 \%$ in the absence of FCS. Thereafter, we focused our experiments on two FCS concentrations: $10 \%$ FCS, a high concentration that is associated to a great cell survival and supposed to induce an activation of BV-2, and 1\% FCS, a low concentration reducing the survival to an acceptable level and supposed to drive BV-2 cells to a 'non reactive' state. To test this hypothesis, we applied the supernatant of BV-2 cells that were grown with $10 \%$ or $1 \%$ FCS on the oligodendroglial $158 \mathrm{~N}$ cell line and analyzed their viability. Whereas, the supernatant of BV-2 grown with 1\% FCS did not induce any loss of $158 \mathrm{~N}$ cells (Figure 1C,D), the supernatant of BV-2 cultured in the presence of $10 \%$ FCS induced a decreased viability of $158 \mathrm{~N}$ (Figure 1E,F). This toxicity indicates that $10 \%$ FCS is able to induce a harmful phenotype in BV-2 cells. To better know these two populations of BV-2, we further characterized them. Thus, the BV-2 cells grown with 1\% FCS make one mitosis per $41 \mathrm{~h}$, as assessed by the dilution of the dye CFSE (Figure 1G,I). In the presence of 10\% FCS, the proliferative rate is significantly sped up to one division per $27 \mathrm{~h}$ (Figure $1 \mathrm{H}, \mathrm{I})$. The cellular morphology is commonly used as an indicator of the activation level that was adopted by microglia. While in the 1\% FCS condition, the cells become adherent and develop processes (Figure 1J), in the 10\% FCS condition, most of the cells are round-shaped (Figure 1K).

A

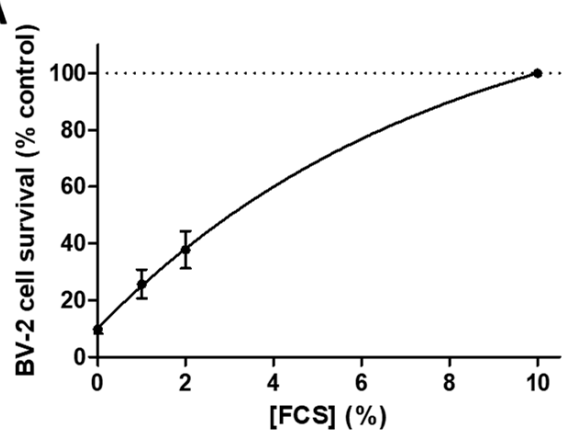

C

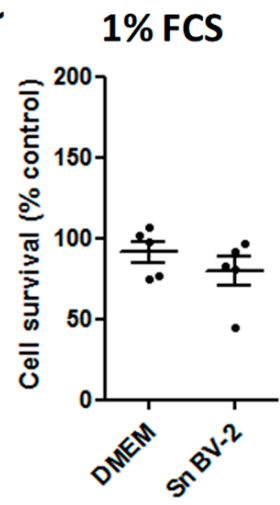

D

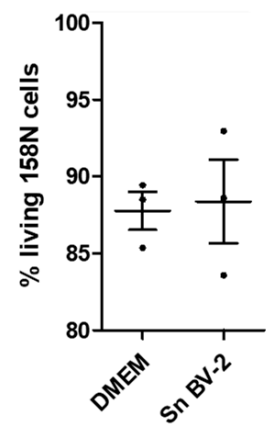

B

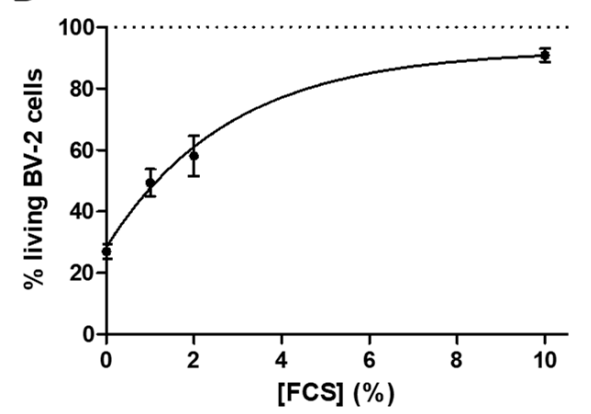

E

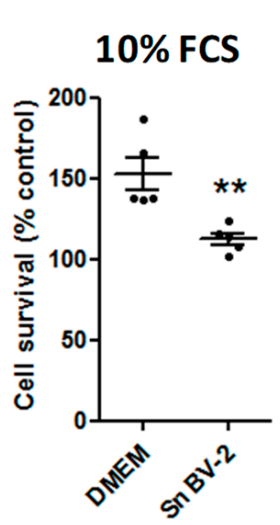

F

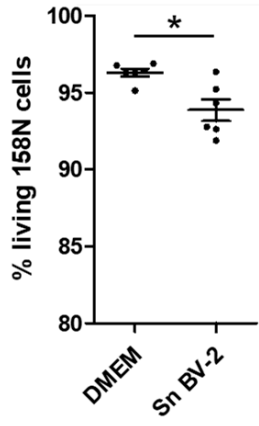

Figure 1. Cont. 

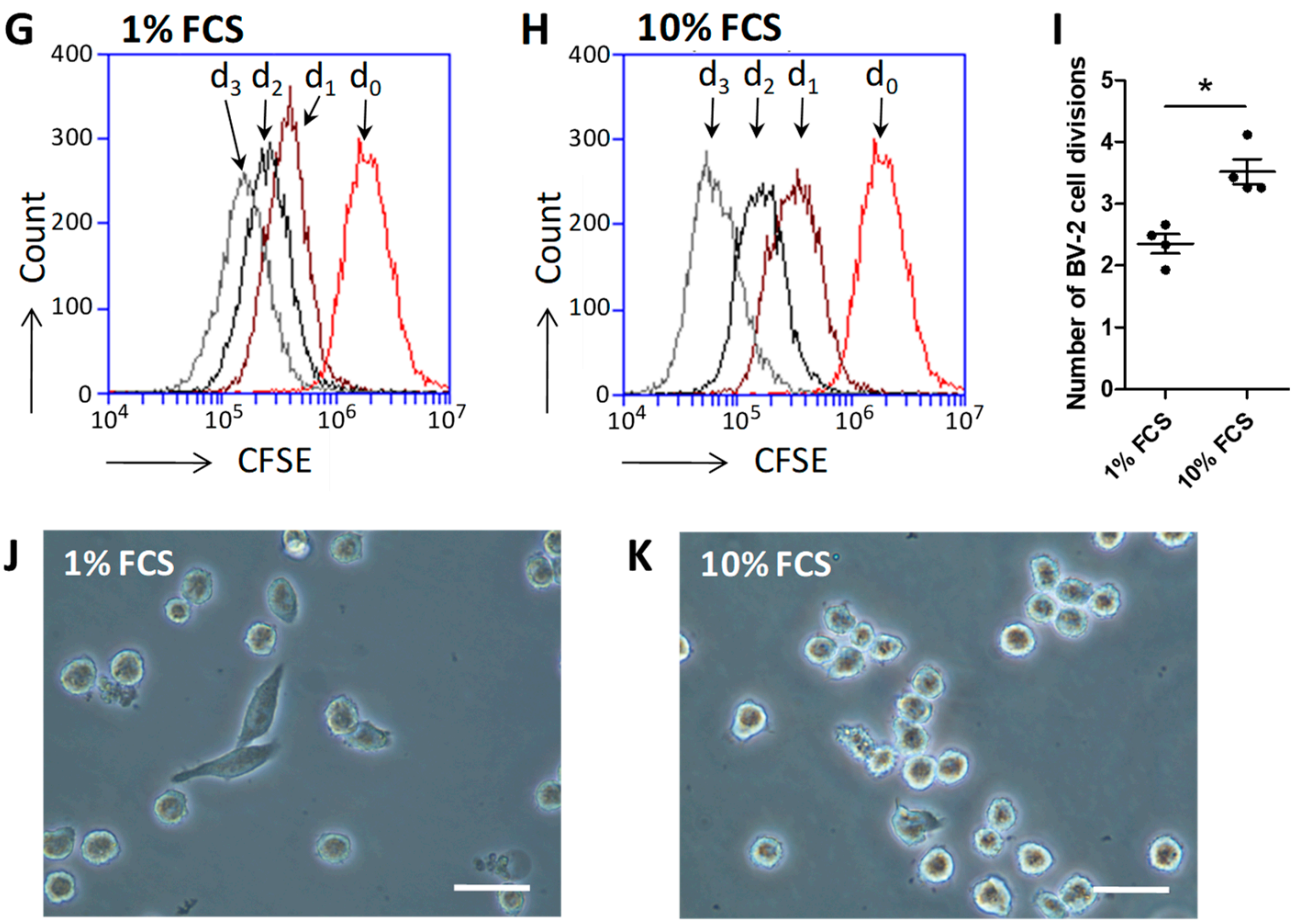

Figure 1. Variations of serum concentrations affect the viability and differentiation of BV-2 cells. (A) The viability of BV-2 cells grown in presence of different serum concentrations was assessed by a MTT assay and corroborated (B) with a 7-AAD viability staining measured by flow cytometry. (C,D) The supernatant of BV-2 grown in a low concentration of serum (1\% Fetal Calf Serum (FCS)) does not modify the survival of $158 \mathrm{~N}$ oligodendrocyte cell line, whereas $(\mathbf{E}, \mathbf{F})$ the supernatant of BV-2 grown in a high concentration of serum $(10 \%$ FCS) reduced significantly the survival of $158 \mathrm{~N}$ cells. (G-I) The Carboxyfluorescein Diacetate Succinimidyl Ester (CFSE) dilution was used to determine the proliferation rate of the BV-2 cells. The CFSE dilution was followed day by day by flow cytometry in the culture condition (G) 1\% FCS or (H) 10\% FCS. D: day. (I) Determination of the number of cell divisions showed that the proliferation of BV-2 cells is reduced in presence of a low concentration of serum. (J) Whereas, in the presence of a low concentration of serum ( $1 \%$ FCS), the BV-2 cells adopted an elongated morphology, $(\mathbf{K})$ they exhibited a rounded shape in presence of a high concentration of serum (10\% FCS). Mean values \pm SEM are shown, from $n=3-4$ independent experiments, ${ }^{*} p<0.05$, ** $p<0.01$.

\subsection{The BV-2 Cell Line Expresses Transcripts of GABA-A Receptors}

ALLO seems to play a crucial role during cerebral diseases, notably thanks to its immunomodulatory activity. Most of the known effects exerted by this neurosteroid are mediated through the GABA-A receptors. To detect possible transcriptional regulations due to the serum concentrations used to cultivate BV-2 cells, the level of expression of specific GABA-A receptor mRNAs was investigated by quantitative PCR. We analyzed the expression of the following subunits normalized to Ppia expression: $\alpha 1, \alpha 2, \alpha 4, \beta 3$, and $\delta$. In our samples, the subunit $\alpha 4$ was not detected, whereas the other subunits were all found. The expression of the subunit $\alpha 1$ was unchanged between BV-2 cells grown with $1 \%$ FCS or $10 \%$ FCS (Figure 2A). On the contrary, there was a significant reduction in the expression of transcripts for the subunit $\alpha 2, \beta 3$, and $\delta$ (Figure 2B-D). Similar results were obtained using other reference genes Hmbs and Pgk1 (data not shown). 
A

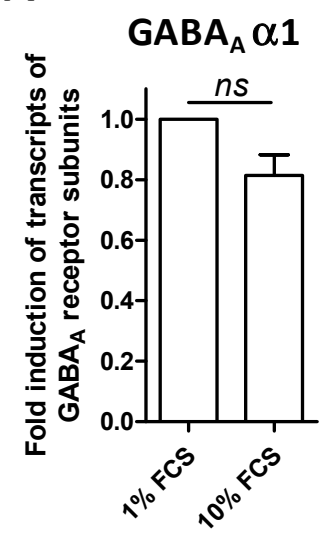

B

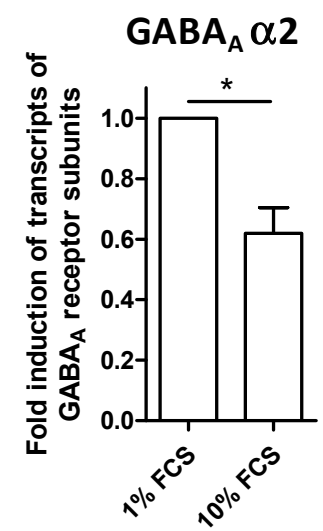

C

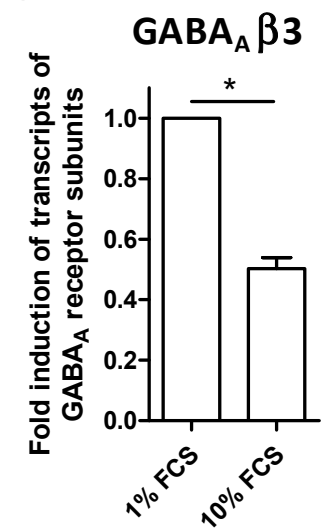

D

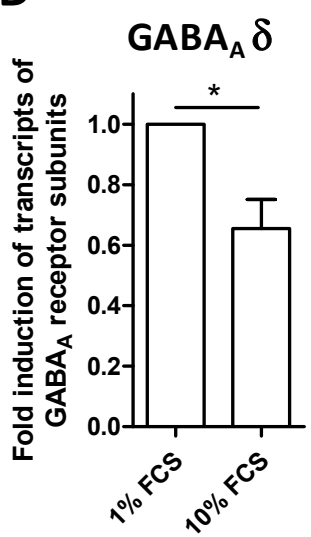

Figure 2. Gene expression of $\gamma$-aminobutyric acid-A (GABA-A) receptor subunits in BV-2 cells. Expression level of GABA-A receptor (A) $\alpha 1,(\mathbf{B}) \alpha 2,(\mathbf{C}) \beta 3$, and (D) $\delta$ subunits in BV-2 cell line are determined by quantitative PCR. The experimental results represent the fold induction of mRNA expressed by BV-2 grown in presence of $10 \%$ FCS in comparison to BV-2 grown with $1 \%$ FCS after normalization to Ppia expression. Mean values \pm SEM are shown, from $n=4$ independent experiments, ${ }^{*} p<0.05$.

\subsection{Effect of ALLO on the Viability of $B V-2$ Cells}

BV-2 cells that were grown in presence of $1 \%$ FCS exhibited a significant reduction of their viability only after incubation with $10 \mu \mathrm{M}$ ALLO (Figure 3A). In contrast, none of the tested doses affected the viability of BV-2 cells cultured in the presence of $10 \%$ FCS (Figure 3B).

A

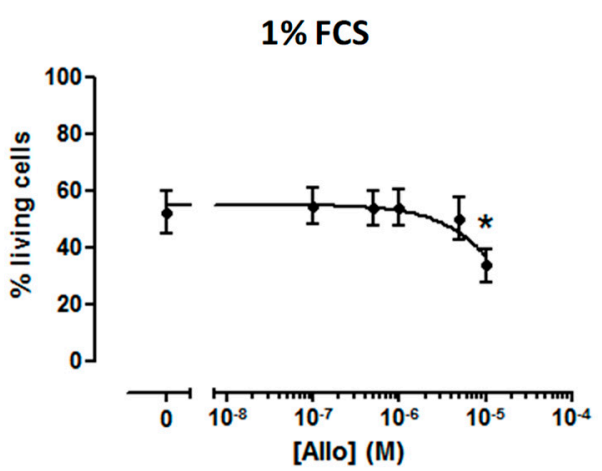

C

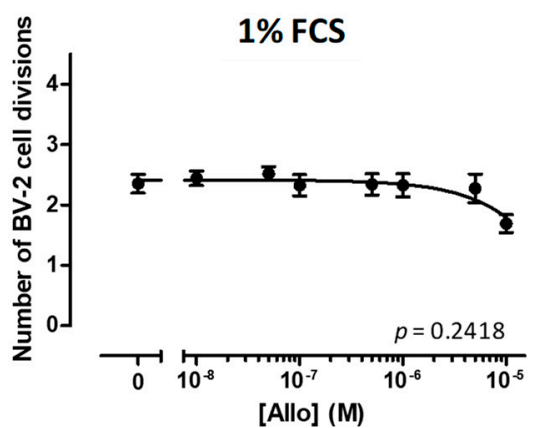

B

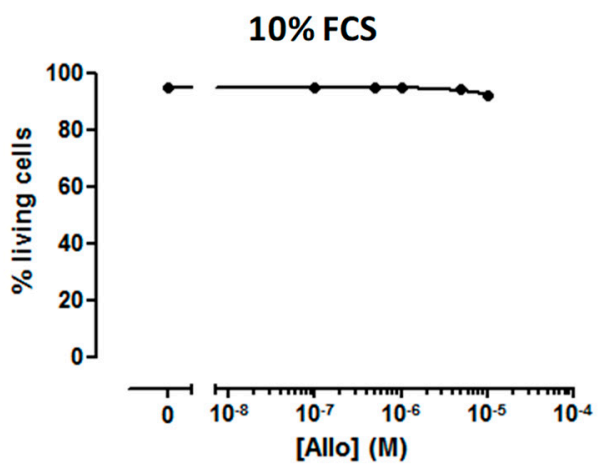

D

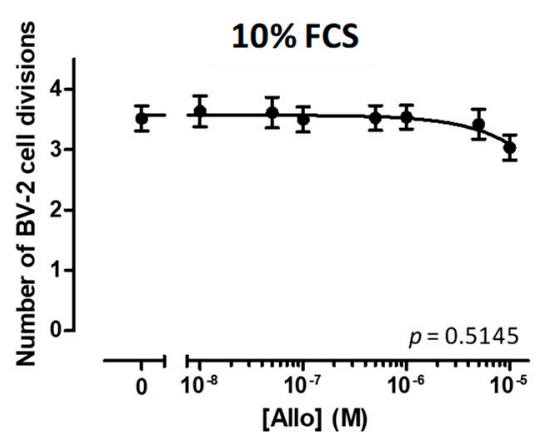

Figure 3. Effect of allopregnanolone (ALLO) on the viability and proliferation of BV-2 cells. (A,B) The viability of BV-2 cells was investigated by flow cytometry following incubation with graded concentrations of ALLO. (C,D) The dilution of CFSE showed that proliferation of BV-2 cells grown with $1 \%$ or $10 \%$ FCS is not modified in presence of ALLO. Mean values \pm SEM are shown, from $n=4$ independent experiments, ${ }^{*} p<0.05$. 


\subsection{ALLO Does Not Modulate Proliferation of the BV-2 Cell Line}

Neurosteroid ALLO has been reported to induce the proliferation of different cell types $[37,38]$. This parameter is important in the context of autoimmune diseases, where an uncontrolled proliferation of immune cells could exacerbate the inflammation. Thus, we analyzed the CFSE dilution in BV-2 cells by flow cytometry after four days of treatment with graded concentrations of ALLO. Whatever the dose of neurosteroid applied to BV-2 cells cultured in the presence of $1 \%$ FCS, the rate of cell division was unchanged (Figure 3C). A similar observation was done if BV-2 cells were grown with 10\% FCS (Figure 3D).

\subsection{ALLO Favors the Elongation of Microglial Processes}

To date, the effects of ALLO on microglia have not been deeply investigated. When grown in the presence of $1 \% \mathrm{FCS}, \mathrm{BV}-2$ cells become adherent and develop processes (Figure $4 \mathrm{~A}$ ). In control conditions, among the BV-2 cells bearing processes, $69 \%$ were bipolar and 31\% were multipolar exhibiting at least three extensions (Figure $4 \mathrm{~B}$ ). One day after the addition of ALLO, none of the tested doses was able to affect the proportion of bipolar vs. multipolar cells (Figure 4B). However, after treatment with $10 \mu \mathrm{M}$ ALLO, BV-2 cells seemed to exhibit longer extensions (Figure 4A). The measurement of the processes borne by each cell revealed that the application of $10 \mu \mathrm{M}$ ALLO led to an increase of $22 \%$ of their mean length (Figure 4C). This extension is found predominantly in bipolar cells (Supplementary Figure S1).
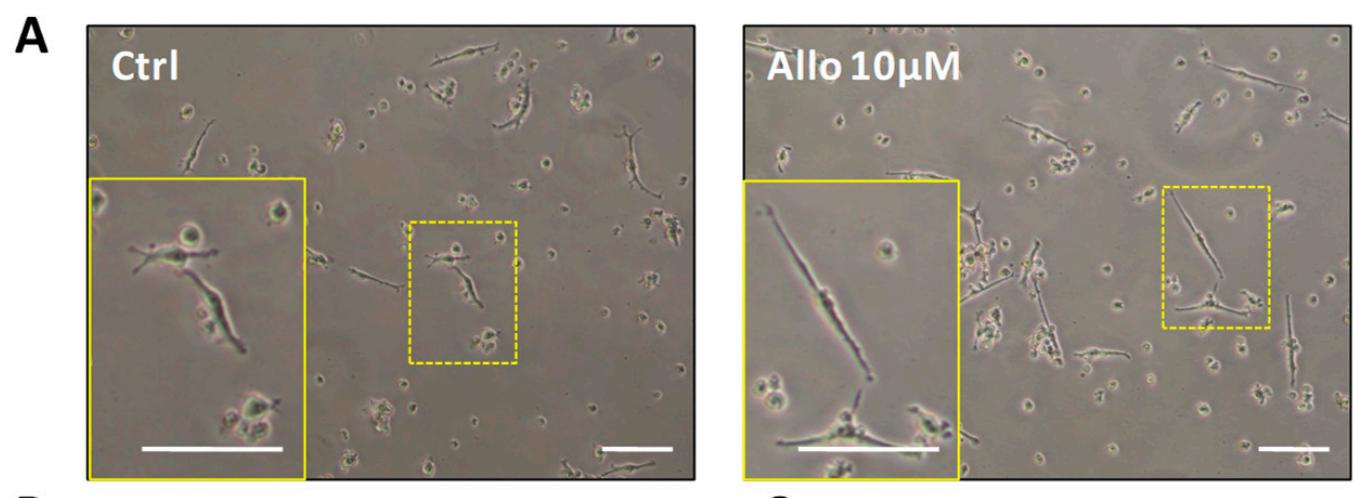

B

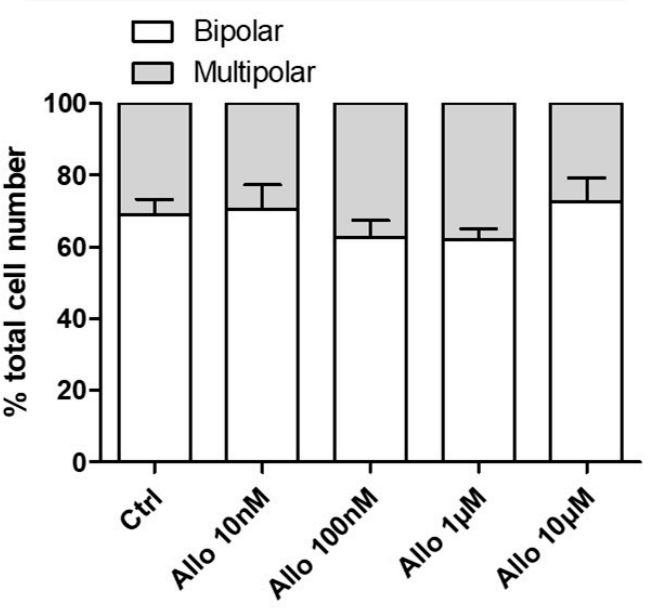

C

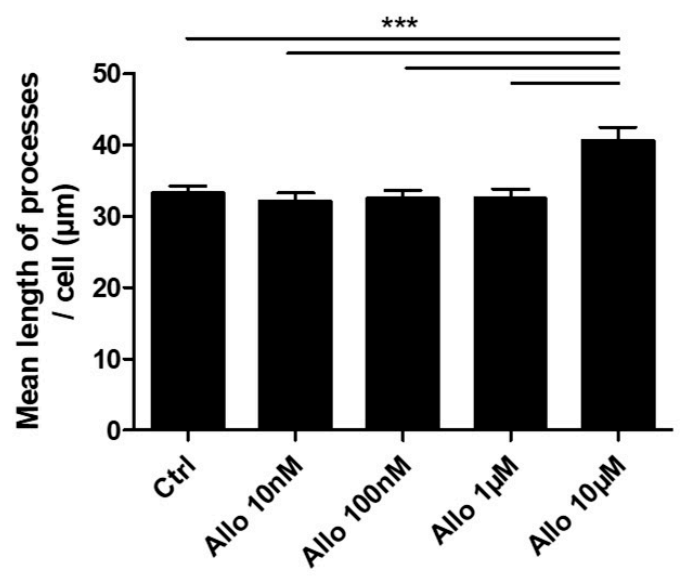

Figure 4. Cont. 


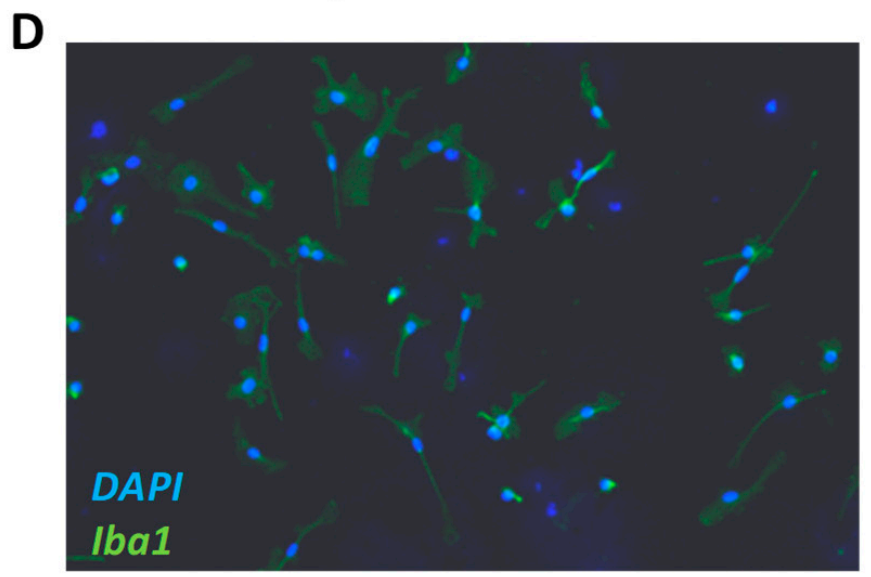

F

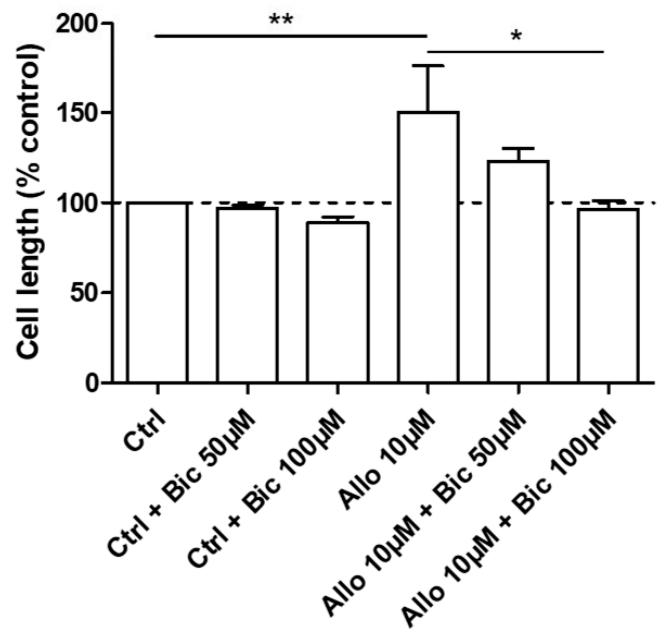

\section{E}

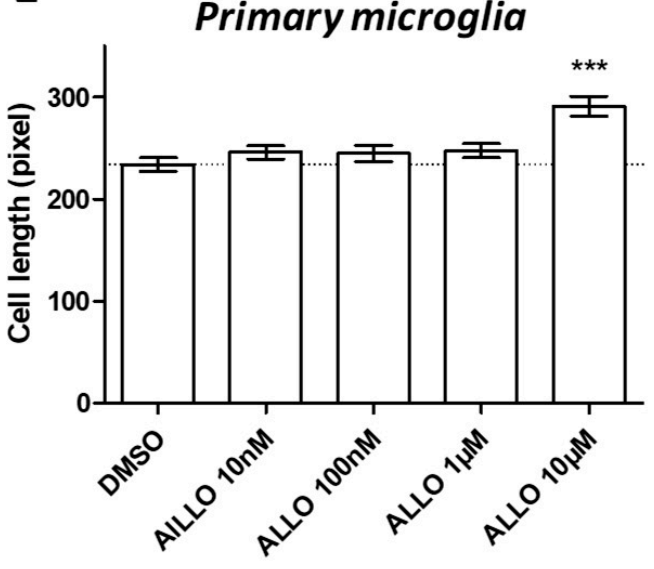

Figure 4. ALLO increases the length of microglial cells. (A) BV-2 cells grown in 1\% FCS exhibited processes in both control and ALLO conditions. Scale bar $=50 \mu \mathrm{M}$. (B) The proportion of bipolar vs. multipolar BV-2 cells (i.e., cells with more than two processes) was not modified after a treatment with ALLO. Mean values \pm SEM are shown, with $n=188$, control cells; $n=141,10 \mathrm{nM}$ ALLO-treated cells; $n=164,100 \mathrm{nM}$ ALLO-treated cells; $n=172,1 \mu \mathrm{M}$ ALLO-treated cells; and $n=154$, $10 \mu \mathrm{M}$ ALLO-treated cells; from $n=$ four independent experiments. (C) The mean length of the primary processes carried by BV-2 was increased after a treatment with ALLO $(10 \mu \mathrm{M})$. Mean values \pm SEM are shown, with $n=136$, control cells; $n=105,10 \mathrm{nM}$ ALLO-treated cells; $n=97,100 \mathrm{nM}$ ALLO-treated cells; $n=106,1 \mu \mathrm{M}$ ALLO-treated cells; and $n=113,10 \mu \mathrm{M}$ ALLO-treated cells; from $n=4$ independent experiments, ${ }^{* * *} p<0.001$. (D) Primary microglial cells that were grown in $1 \%$ FCS exhibited processes that had an increased length after incubation with ALLO $(10 \mu \mathrm{M})$. Scale bar $=50 \mu \mathrm{M}$. (E) The mean length of primary microglial cells was increased after a treatment with ALLO (10 $\mu \mathrm{M})$. Mean values \pm SEM are shown, with $n=291$, control cells; $n=391,10 \mathrm{nM}$ ALLO-treated cells; $n=289,100 \mathrm{nM}$ ALLO-treated cells; $n=306,1 \mu \mathrm{M}$ ALLO-treated cells; and, $n=274,10 \mu \mathrm{M}$ ALLO-treated cells; from five independent experiments, ${ }^{* * *} p<0.001$. (F) The effect of ALLO on BV-2 cell morphology is mediated by the GABA-A receptor. The application of bicuculline (Bic) before the treatment with ALLO $(10 \mu \mathrm{M})$ abolished the ALLO-induced elongation of the processes carried by bipolar BV-2 cells. Mean values \pm SEM are shown, from $n=$ four independent experiments, ${ }^{*} p<0.05,{ }^{* *} p<0.01$.

To note, the effect of ALLO on BV-2 morphology does not seem to be dependent of FCS concentration and, therefore, of BV-2 activation level. When these cells are cultured with $10 \%$ FCS, they barely develop processes, so we could not use the length of their extensions as an appropriate readout. Instead, we quantified the number of cells that showed a clear adherence to the plastic dish. Thus, in the presence of $10 \mu \mathrm{M}$ ALLO, we could observe more cells exhibiting processes (Supplementary Figure S2A). Indeed, $14.2 \%$ of the cells were adherent in control conditions, whereas they were $19.2 \%$ after the addition of $10 \mu \mathrm{M}$ ALLO (Supplementary Figure S2B). 
Morphological analyses were also conducted on primary murine microglia cultured in $1 \%$ FCS. Immunostainings revealed that, in our experimental conditions, a high purity of microglia was achieved (Figure 4D). This was further confirmed by flow cytometry (Supplementary Figure S3). As expected, primary microglia exhibited processes when treated with vehicle. In the presence of $10 \mu \mathrm{M}$ ALLO, the length of the cells was also significantly increased (Figure $4 \mathrm{D}, \mathrm{E}$ ). This result indicates that the BV-2 cell line and primary murine microglia both react in a similar manner to ALLO application. It also suggests that BV-2 cells may represent a valuable tool for dissecting the effect of ALLO on microglia.

ALLO is known to mediate effects via the GABA-A receptor. To investigate the implication of this receptor, bicuculline, a competitive antagonist of GABA-A receptors, was applied $30 \mathrm{~min}$. before the incubation of the BV-2 cells with $10 \mu \mathrm{M}$ ALLO. Bicuculline could prevent the elongation of the BV-2 cells in a dose-dependent manner (Figure 4F). The inhibition was complete with $100 \mu \mathrm{M}$ bicuculline, a dosage that has already been used to modulate microglia $[13,39]$. This indicates that the observed cell length increase that was induced by ALLO was mediated by the GABA-A receptor.

\subsection{ALLO Reduces the Motility of Microglia}

Previous work that was realized by coauthors showed that a bipolar shape is associated with a more efficient migratory ability [40]. Because both primary microglia and BV-2 cells were more elongated following treatment with $10 \mu \mathrm{M}$ ALLO, an effect on their motility was suspected. By using time-lapse imaging, the displacement of BV-2 cells grown in the presence of $1 \%$ FCS was analyzed in control conditions and after the addition of $10 \mu \mathrm{M}$ ALLO. The movement of the nucleus was followed during $2 \mathrm{~h}$. Unexpectedly, the cells that were treated with ALLO (that have the more elongated shape) appeared to be less motile. The mean path length underwent by BV-2 cells in the presence of ALLO was reduced by $22.6 \%$ during the acquisition time (Figure $5 \mathrm{~B}$ ). On the contrary, the distance traveled between the position at $\mathrm{t} 0$ and at $\mathrm{t} 2$ hours was not modified by the treatment (Figure 5C). The analysis of the directionality, i.e., the ratio between the distance t 0 to 2 hours and the path length, indicated that the control BV-2 cells do not exhibit a persistent movement with a ratio of 0.21 (Figure 5D). This is consistent with the absence of any localized chemotactic signal in the culture conditions. The application of ALLO did not modify this parameter (Figure 5D). If we consider the mean and the maximum velocities (Vmax), the application of ALLO led to their significant reduction by $14.3 \%$ and $16.7 \%$, respectively (Figure 5E,F).

\subsection{Effect of ALLO on the Deleterious Activity Exerted by Reactive Microglial Supernatants on} Oligodendrocytes

The supernatant of the activated BV-2 cells was able to alter the viability of the oligodendroglial $158 \mathrm{~N}$ cell line in culture, as shown before (Figure 1E,F). We investigated whether the addition of ALLO on BV-2 cells that were grown with $10 \%$ FCS was able to counteract this deleterious effect. In presence of DMEM completed with $10 \%$ FCS, the $158 \mathrm{~N}$ cells exhibit a high viability of $96 \%$ as determined by the exclusion of 7-AAD (Figure 6A). The addition of the supernatant from BV-2 cells led a significant decreased viability of $158 \mathrm{~N}$ cells. The pre-incubation of BV-2 cells with graded concentrations of ALLO from 10 $\mathrm{nM}$ to $10 \mu \mathrm{M}$ did not significantly improve the viability of $158 \mathrm{~N}$ (Figure $6 \mathrm{~A}$ ). In order to know whether this neurosteroid could affect directly the viability of $158 \mathrm{~N}$ cells, these cells were incubated in the presence of graded concentrations of ALLO. We could not detect any significant decrease of the $158 \mathrm{~N}$ cell survival with the doses from $10 \mathrm{nM}$ until $10 \mu \mathrm{M}$ ALLO, doses used to counteract the deleterious activity of supernatants from reactive BV-2 cells (Figure 6B). Only the higher dose of $50 \mu \mathrm{M}$ reduced the viability of $158 \mathrm{~N}$ cells (Figure $6 \mathrm{~B}$ ). Of note, incubation with ALLO did not modify the proliferation of $158 \mathrm{~N}$ cells (Figure 6C). 
A
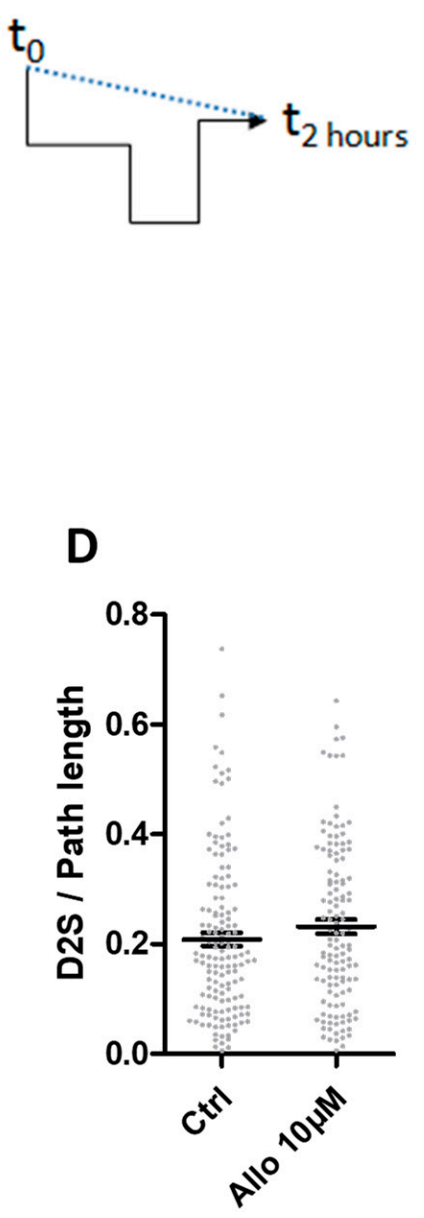

B

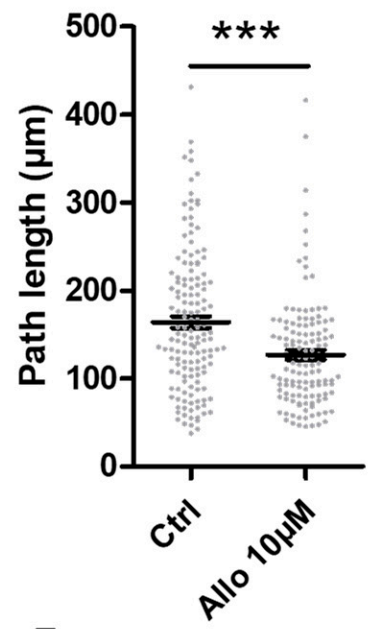

E

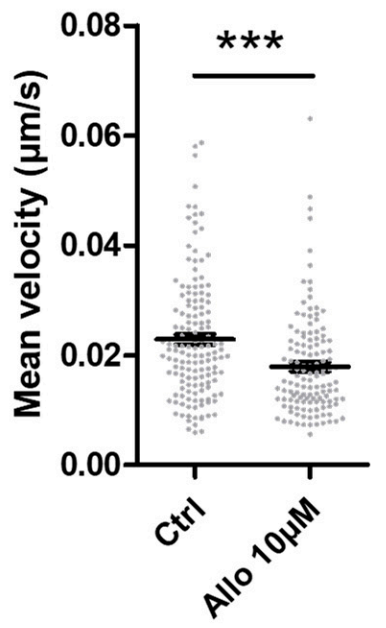

C

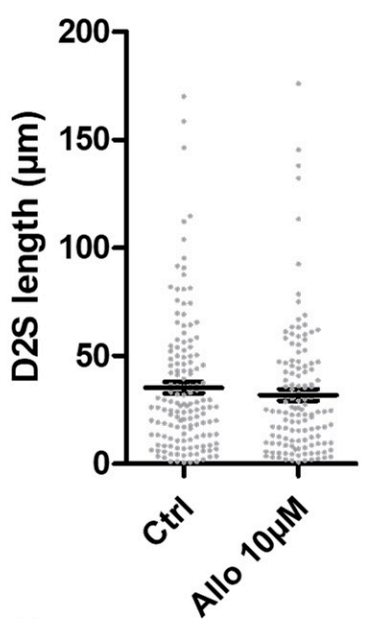

$\mathbf{F}$

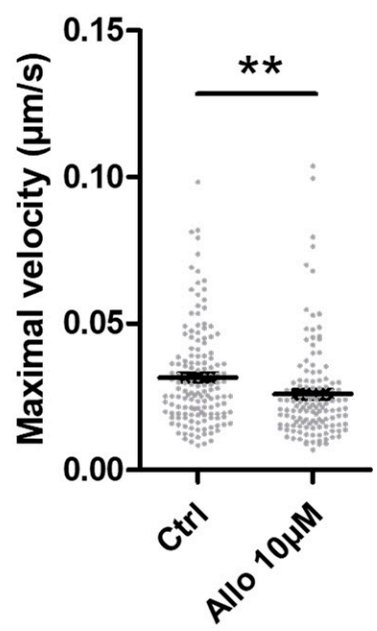

Figure 5. ALLO modifies the motility of BV-2 cells grown in a low concentration of serum. (A) The path length represents the total path traveled by the cells during the experiment (black line). D2S is the distance between the start and the end point (dotted blue line). (B) The path length and (C) the distance traveled between the first and the last position of the BV-2 cells (D2S length) were measured from time-lapse imaging. (D) The directionality (i.e., the ratio D2S length/path length), (E) the mean velocity and (F) the maximal velocity of BV-2 cells were subsequently determined. BV-2 cells were grown in $1 \%$ FCS. Mean values \pm SEM are shown, with $n=146$ control cells and $n=129$ ALLO-treated cells, from four independent experiments, ${ }^{* *} p<0.01,{ }^{* * *} p<0.001$.

\subsection{ALLO Modulates the Phagocytic Activity of Reactive Microglia}

ALLO, besides its well-known neuroprotective action, can also modulate immune cell activity [41]. Phagocytosis represents an immunological function exerted by microglia that is highly dependent on the dynamics of the cytoskeleton. Moreover, serum exposure is known to enhance phagocytosis [11]. To investigate the potential action of ALLO on phagocytosis, microglial cells were incubated either with 70kDa FITC-dextran or $1 \mu \mathrm{m}$ FITC-latex beads. The internalization of FITC-dextran was significantly reduced when BV-2 cells were pre-treated with $10 \mu \mathrm{M}$ ALLO (Figure 7A). The uptake of larger particles, like latex beads, was also impaired by ALLO treatment, as demonstrated by the decreased MFI that was measured by flow cytometry (Figure 7B). The proportion of cells having engulfed latex beads is also decreased after the application of ALLO.

Very interestingly, a similar finding was observed with primary microglia treated with $10 \mu \mathrm{M}$ ALLO. Indeed, these cells exhibited a significantly lower capacity to take FITC- 
dextran (Figure 7C). Microglia are considered to be the resident macrophage population of the CNS. FITC-dextran uptake was also analyzed in the Raw264.7 cell line and in peritoneal macrophages in order to assess whether the inhibitory action of ALLO on phagocytic activity was general on other macrophage populations. The addition of $10 \mu \mathrm{M}$ ALLO on Raw264.7 cells led to a significantly decreased internalization of FITC-dextran in comparison to control cells (Figure 7D). More interestingly, macrophages directly derived from the peritoneal cavity of adult mice also exhibited a reduced phagocytic capacity after the application of ALLO (Figure 7E). These reproducible results obtained with various cells indicate the robust effect of ALLO on phagocytosis.

Bicuculline was used to understand the mechanism leading to the decreased uptake by microglia. A pre-treatment with this GABA-A antagonist was not able to prevent the inhibited FITC-dextran uptake produced by $10 \mu \mathrm{M}$ ALLO (Figure 7F). This result suggests that this effect was independent of GABA-A signaling. Moreover, to exclude that this inhibitory effect generated by $10 \mu \mathrm{M}$ ALLO was due to a potential toxic effect, we analyzed apoptotic and necrotic markers. The incubation of BV-2 cells with $10 \mu \mathrm{M}$ ALLO did not modify the percentage of caspase-3 positive cells, as measured by flow cytometry (Figure 7G). Using the markers PI and annexin-5, we could also determine the ratio of cells in healthy condition, early or late apoptosis, and undergoing necrosis (Figure $7 \mathrm{H}$ ). In the control culture, the vast majority of BV-2 cells consisted of living cells negative for both PI and annexin-5. Less that 5\% accounted for dead and dying cells (Figure $7 \mathrm{H}$ ). The application of $10 \mu \mathrm{M}$ ALLO did not alter the ratios of the different populations (Figure 7H). Thus, ALLO modified the phagocytic capacity of BV-2 cells independentof any deleterious effect.
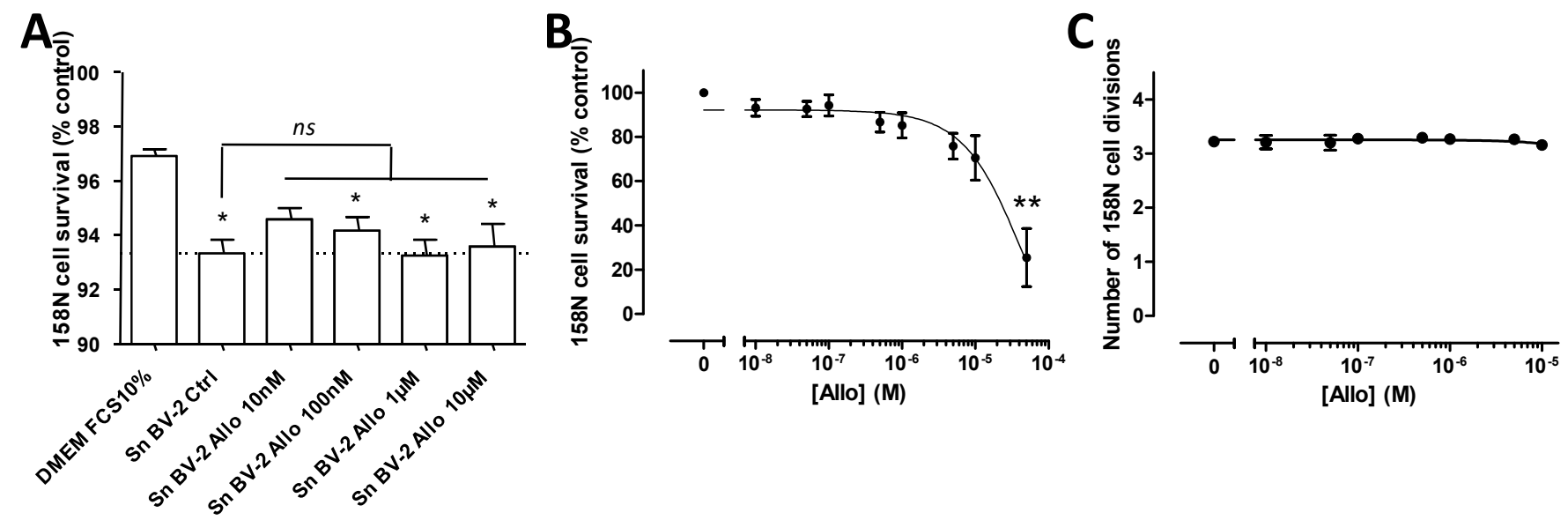

Figure 6. Effect of ALLO on reactive BV-2 cell derived supernatants in the modulation of oligodendrocyte survival. (A) The incubation of BV-2 with graded concentrations of ALLO from $10 \mathrm{nM}$ to $10 \mu \mathrm{M}$ did not modify the toxicity of their supernatants towards the oligodendrocyte $158 \mathrm{~N}$ cell line. Mean values \pm SEM are shown, from $n=4$ independent experiments, ${ }^{*} p<0.05$ versus 'DMEM FCS10\%', ns: non-significant. (B) The effect of graded concentrations of ALLO on the viability and $(\mathbf{C})$ on the proliferation of the $158 \mathrm{~N}$ cells. Mean values \pm SEM are shown, from $n=3-4$ independent experiments, ${ }^{*} p<0.05,{ }^{* *} p<0.01$. 

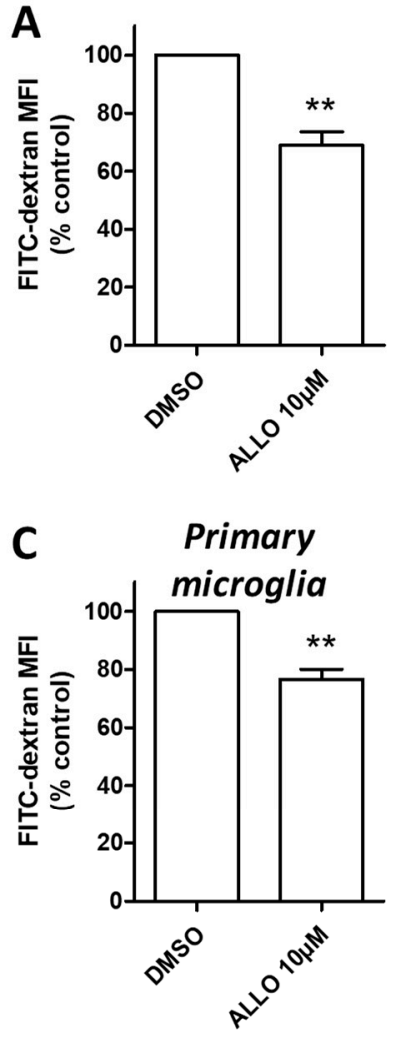

$\mathbf{F}$

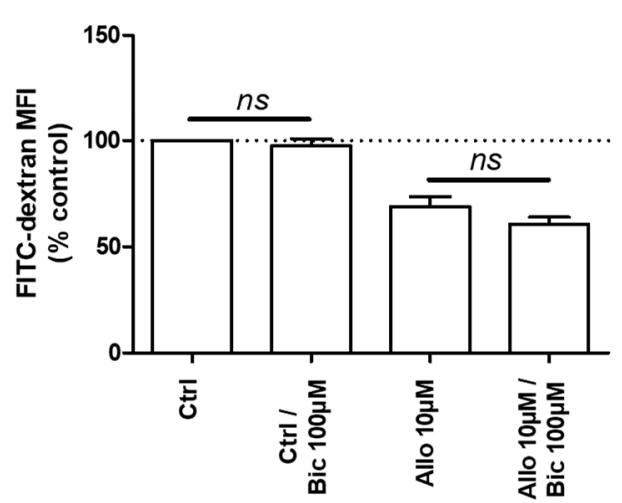

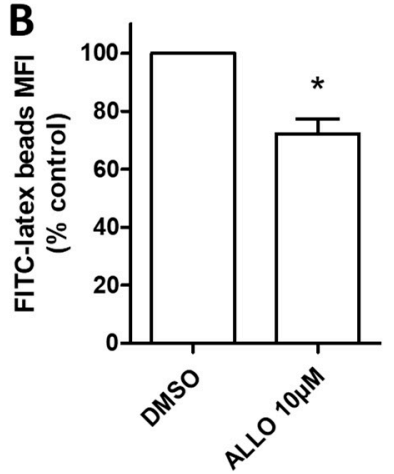

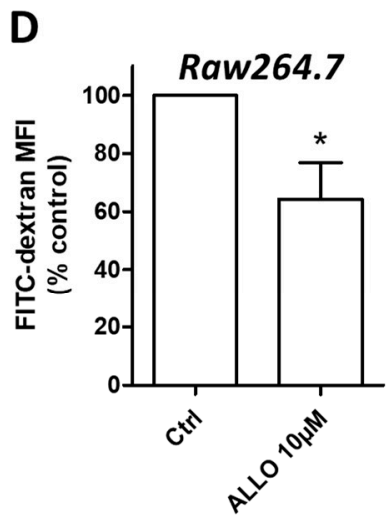

G

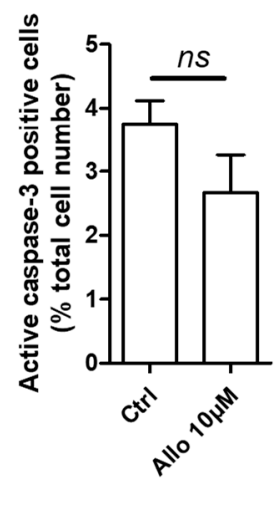

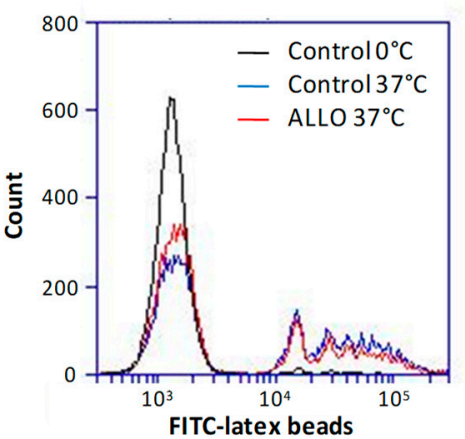

E

Peritoneal

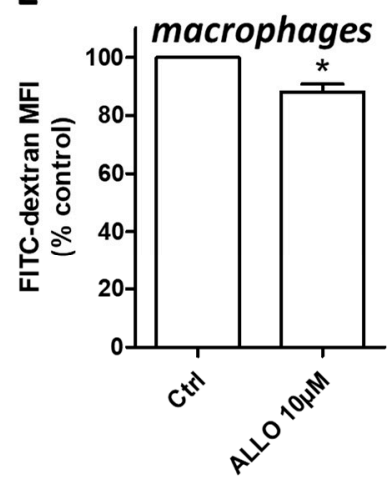

H

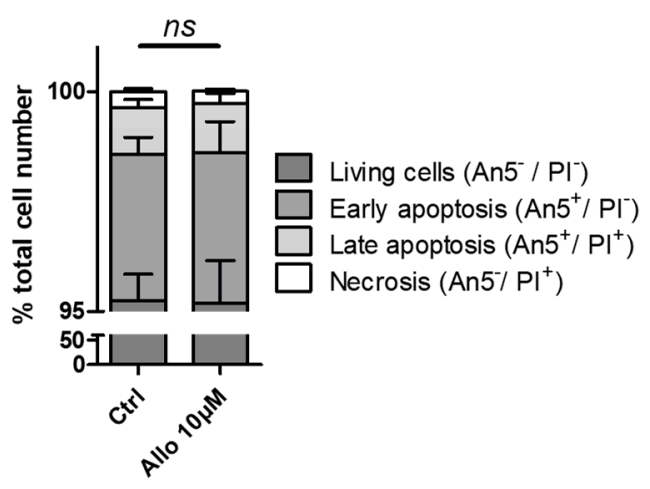

Figure 7. ALLO reduces the phagocytic activity of microglial cells grown in a high concentration of serum. (A) Application of $10 \mu \mathrm{M}$ ALLO inhibits 70kDa FITC-dextran (B) as well as $1 \mu \mathrm{m}$ FITC-latex beads uptake by BV-2 cells. (C) Primary murine microglia engulf also significantly less FITC-dextran after treatment with ALLO. (D) Murine macrophages such as the Raw 264.7 cell line or (E) peritoneal macrophages are also sensitive to ALLO that reduces significantly their FITC-dextran uptake. Mean values \pm SEM are shown, from $n=4-6$ independent experiments, ${ }^{*} p<0.05$. (F) Effect of bicuculline on the reduced phagocytic activity induced by $10 \mu \mathrm{M}$ ALLO on BV-2 cells. (G) The treatment of BV-2 with $10 \mu \mathrm{M}$ ALLO does not induce apoptosis, as revealed by caspase-3 intracellular staining or (H) annexin5 (An5)/propidium iodide (PI). Mean values \pm SEM are shown, from $n=3-4$ independent experiments, ${ }^{*} p<0.05,{ }^{* *} p<0.01$.

\subsection{ALLO Inhibits the Inappropriate and Unexpected Phagocytosis of Oligodendrocytes by Reactive Microglia}

In order to investigate whether the activation of microglia could lead to an inappropriate phagocytosis of oligodendrocytes, we designed an in vitro model where activated BV-2 cells grown in presence of $10 \%$ FCS and expressing the red fluorescent molecule tomato were co-cultured with $158 \mathrm{~N}$ cells that were previously stained with the green fluorescent CFSE (Figure 8). Oligodendroglial 158N are adherent cells presenting short elongations and are devoid of red fluorescence (Figure 8A-D). In the presence of BV-2 cells, they ex- 
hibit a similar morphology (Figure $8 \mathrm{E}-\mathrm{H}$ ). The activated BV-2 cells are mostly rounded (Figure 8E-K). Some BV-2 cells contain green fluorescence derived from phagocytized oligodendroglial 158N (Figure $8 \mathrm{I}-\mathrm{K}$ ). When the BV-2 cells were previously grown in the presence of $10 \%$ FCS, $2.07 \%$ of these cells were found to have phagocytized $158 \mathrm{~N}$ cells. The pre-treatment of BV-2 cells with $10 \mu \mathrm{M}$ ALLO significantlyreduced the inappropriate phagocytosis of $158 \mathrm{~N}$ cells (Figure $8 \mathrm{~L}$ ).

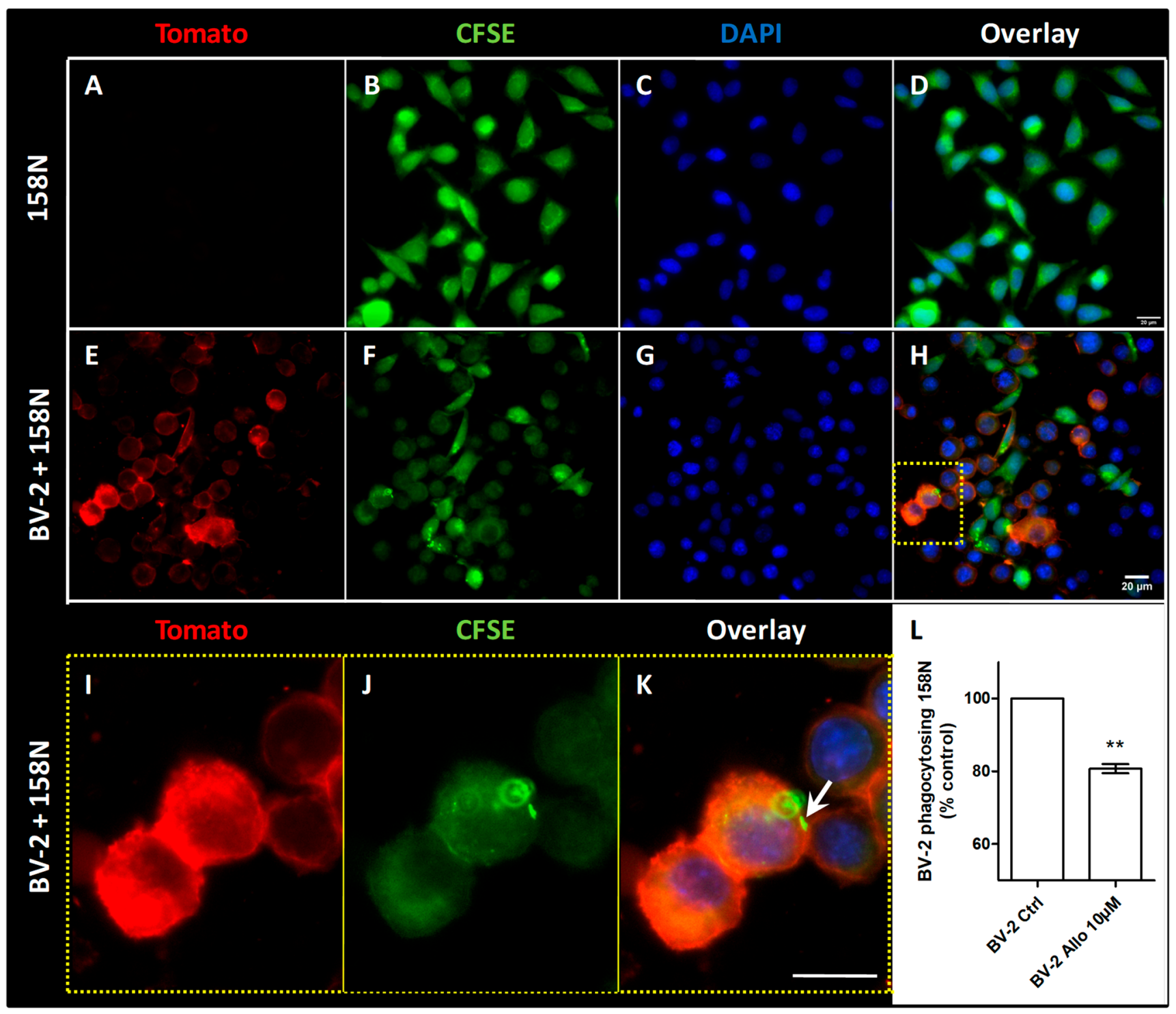

Figure 8. ALLO inhibits the inappropriate phagocytosis of oligodendroglial $158 \mathrm{~N}$ cells by microglial BV-2 cells. (A-K) Microscopic observation of $158 \mathrm{~N}$ cells either alone (A-D) or in coculture with BV-2 cells (E-K). BV-2 cells express the red fluorescent protein Tomato $(\mathbf{E}, \mathbf{H}, \mathbf{I}, \mathbf{K})$ and $158 \mathrm{~N}$ cells are previously stained with the green fluorescent compound CFSE $(\mathbf{B}, \mathbf{D}, \mathbf{F}, \mathbf{H}, \mathbf{J}, \mathbf{K})$. The nuclei are observed by DAPI (C,D,G,H,K). The fluorescent signals detected in each channel are presented overlaid $(\mathbf{D}, \mathbf{H}, \mathbf{K})$. The BV-2 cells observed in the yellow dashed box of the microphotograph $(\mathbf{H})$ are shown with a higher magnification (I-K). One BV-2 cell contains green fluorescence derived from a phagocytized 158N cell (arrow). Scale bar $=20 \mu \mathrm{m}$. (L) Flow cytometric measurement of red fluorescent BV-2 cells having phagocytized green fluorescent $158 \mathrm{~N}$. Mean values \pm SEM are shown, from $n=$ five independent experiments, ${ }^{* *} p<0.01$.

\section{Discussion}

We used both murine primary microglia and the BV-2 cell line to analyze the effects of neurosteroid ALLO on microglia in physiological and pathological conditions. BV-2 cells represent an effective substitute for microglial primary cultures [42]. Indeed, when 
exposed to lipopolysaccharides, $90 \%$ of the genes induced by primary microglia were also induced by BV-2 cells. Moreover, BV-2 cells are commonly employed as an in vitro model of neuroinflammation. Thus, we used BV-2 cells to screen multiple parameters in order to investigate the effects of ALLO on microglial cells. Furthermore, to increase the pathophysiological significance of our findings, the relevant results that were obtained with BV-2 cells were validated in primary microglial cultures that are conventionally well accepted as the most reliable cell model to reproduce in vitro the conditions occurring in vivo.

Serum is not found within the parenchyma of a healthy CNS. In pathological conditions, the rupture of the $\mathrm{BBB}$ allows for the passage of large quantities of blood components. The exposure of microglia to serum leads to functional and transcriptomic modifications in both BV-2 cells and primary microglia [11,43]. For instance, when cultured with a reduced concentration of FCS, both BV-2 cells and primary microglia adopt a processbearing morphology that is typical of highly ramified surveillant microglia. In contrast, in the presence of a high concentration of serum, BV-2 and primary microglia exhibit a round amoeboid shape, a representative morphology of fully activated microglia typically found in the injured brain $[11,43]$. Phagocytic activity that is exerted by microglia is also related to FCS concentration. This first line of defense mechanism is highly active in primary microglia grown in the presence of 10\% FCS [44]. In contrast, in the absence of serum, primary microglial cells barely engulf any particle [11]. The serum-induced microglial phagocytosis may be due to signals that are normally excluded from the CNS environment and, therefore, linked to BBB integrity [44]. Indeed, an in vivo model of neuroinflammation in which the BBB is maintained, like peripheral LPS injection, did not demonstrate enhanced phagocytosis [45]. In contrast, debris uptake by microglia has been documented in neuropathologies, where BBB is compromised, such as stroke or multiple sclerosis $[46,47]$. Phagocytosis is now recognized as a critical mechanism for neuroprotection and regeneration that is regulated by serum factors. Moreover, we could demonstrate that the supernatant derived from BV-2 cells cultured with high serum was harmful to the $158 \mathrm{~N}$ oligodendrocyte cell line, suggesting that they may have secreted deleterious factors. In contrast, no modification of $158 \mathrm{~N}$ oligodendrocyte viability was observed when they were incubated with the supernatant from BV-2 cells grown in the presence of a low concentration of FCS. Therefore, serum represents a valuable activation factor to mimic compromised BBB found in neuropathologies, such as multiple sclerosis. Thus, we considered having two experimental conditions: BV-2 cells in 'resting' state to mimic the physiological condition (i.e., grown with $1 \%$ FCS), and reactive BV-2 cells to mimic a pathological state (i.e., grown with $10 \%$ FCS).

Neurosteroid ALLO is known to exert neuroprotection in numerous neurological diseases, in particular MS [20]. To date, the underlying mechanisms are poorly understood, especially the ones leading to the modulation of microglial activity. In a physiological microenvironment, the microglial cells have a small soma bearing long and thin extensions. Upon activation, a gradual morphological transformation is marked by the retraction of cellular processes. For this reason, the analysis of microglial morphology is widely used to quantify their activation when their involvement is investigated in neurological diseases, such as stroke $[48,49]$ or multiple sclerosis $[50,51]$. In this report, we found that the addition of ALLO led to morphological modifications of BV-2 cells and primary microglia, which exhibited longer processes. This morphological modification may represent the shift of the cells towards a more resting state. Interestingly, we also report that this elongated shape is associated with a reduced migratory capacity. The somata of resting microglial cells remain fixed, as revealed by in vivo two-photon microscopy [4]. In contrast, the microglial cells have been shown to exhibit a migratory activity in neuropathological conditions. For instance, they migrate in the direction of a forebrain stab lesion [52] or towards newly forming plaques in an animal model of Alzheimer's disease [53]. Interestingly, a similar morphological modification has been evidenced while using Schwann cells. In the presence of $1 \mu \mathrm{M}$ ALLO, these cells adopt the typical spindle-shaped morphology [54]. The actin 
rearrangements that are induced by ALLO involved the signaling pathway Src/FAK $(\mathrm{Src}=$ proto-oncogene tyrosine-protein kinase; FAK: focal adhesion kinase) and GABA-A dependent mechanisms [54]. The elongation of extensions borne by BV-2 reported appeared here to be mainly mediated by the GABA-A receptor, as it was completely reversed by the application of bicuculline, a competitive antagonist at the GABA-binding site of the GABA-A receptor.

Phagocytosis constitutes a fundamental activity of innate immune cells. In multiple sclerosis, myelin phagocytosis represents a pathological hallmark. By using two different substrates in the present work, we demonstrate an inhibitory activity being exerted by ALLO on microglial phagocytic function. More interestingly, in a coculture experiment, we show that phagocytosis of oligodendrocytes, the cells forming the myelin sheath in the CNS, is also decreased after the treatment of microglia by ALLO. Impaired expressions of homeostatic molecules have been reported to point to the onset of uncontrolled phagocytosis by microglia in MS lesions [55]. Thus, the modulation of phagocytosis appears critical to improve this pathology.

GABA-A receptors are pentameric ligand-gated ion channels that can be composed with various subunits $(\alpha, \beta, \gamma, \delta, \varepsilon, \theta, \pi$, and $\rho)$ and they exhibit a variety of allosteric binding sites [56]. Some pharmacological properties are critically linked to the subunit combination that is found within the receptor. For instance, the exclusive extrasynaptic presence of GABA-A receptors formed with $\alpha-\beta$ or $\alpha-\beta-\delta$ subunits is known to exert a tonic inhibition of neurons [57]. Murine microglial cells were shown to express the mRNA of 15 subunits ( $\alpha 1-5, \beta 1-3, \gamma 1-3, \delta, \varepsilon, \rho 1-2)$ [18] and exhibit functionally active GABA-A receptors [13]. Regarding the GABA-A receptor subunits that are expressed by BV-2 cell line, we found the expression of mRNA coding for $\alpha 1$, as previously described [39], as well as $\alpha 2, \beta 3$, and $\delta$. On the contrary to $\alpha 1$, the transcripts of $\alpha 2, \beta 3$, and $\delta$ were more expressed in cells that were grown with $1 \%$ FCS. The subunit $\alpha 2$ has been recently found to be implicated in the inflammatory activation of monocyte/macrophage RAW264.7 cell line following LPS stimulation [58]. In particular, we investigated the expression of the $\delta$ subunit because neurosteroids have preferential affinity for $\delta$-containing GABA-A receptors [59]. Moreover, $\delta$ subunit-containing receptors exhibit a high affinity for GABA and can be activated by low nanomolar concentrations of GABA that spill over the synaptic cleft or are released by glial cells [60]. Interestingly, the subunit $\beta 3$, reported to form homo-oligomeric GABA-A receptors, also contains a steroid-binding site at the transmembrane domain 3 [61]. Thus, a higher expression of $\beta 3$ and $\delta$ GABA-A subunits in BV-2 cells that were grown in $1 \%$ FCS might lead to a higher affinity of ALLO for the GABA-A receptors. In the present report, we could demonstrate that the same dose of $10 \mu \mathrm{M}$ ALLO was able to modify the morphology of BV-2 cells grown with 1\% FCS as well as the phagocytic function of BV-2 cells grown with $10 \%$ FCS. Accordingly, there is no mismatch of the efficient dose that is able to modify either morphology or phagocytosis despite the potential modified expression of GABA-A receptor subunits in these cells. We did not evaluate the transcription of the other subunits that might be upregulated as a compensatory mechanism. Additionally, we did not assess whether these transcriptomic modulations would be translated at the protein level. Thus, we cannot conclude on the total concentration of GABA-A receptors that would be found at the microglial membrane surface, either upon $1 \%$ or $10 \%$ FCS.

The activity of ALLO is known to be notably mediated through the GABA-A receptor by a concentration-dependent mechanism [62]. The only significant effects of ALLO that are shown in the present study are observed with the concentration $10 \mu \mathrm{M}$. Interestingly, a concentration of $10 \mu \mathrm{M}$ ALLO has previously been reported to decrease NO secretion by BV-2 cells [41] or reduce pro-inflammatory cytokine transcription by primary rat microglial cells [63]. At low nanomolar concentrations, ALLO acts as a positive allosteric modulator enhancing the action of the natural ligand GABA, whereas, at micromolar concentrations, this neurosteroid directly activates the receptors even in the absence of GABA [60,64,65]. This profile is explained by the presence of two distinct neurosteroid binding sites in the GABA-A receptor's transmembrane domains, which are distinct from the GABA binding 
site. Neurosteroids at nanomolar concentrations potentiate GABA responses from the 'potentiation site' that is formed by the $\alpha$-subunit transmembrane domains. Micromolar concentrations of neurosteroids directly activate GABA-A receptor by binding to the 'activation' site located between $\alpha$ and $\beta$ subunits. Thus, significant GABA-A receptor activation by neurosteroids relies on occupancy of both the activation and potentiation sites [60]. Moreover, using exogenous systems like HEK2293 cells, neurosteroids were shown to enhance the current that is evoked by low concentrations of GABA, but not the current evoked by saturating concentrations of GABA [66]. Thus, neurosteroids increase the GABA efficacy of these receptors by converting GABA from a partial to full agonist [67]. It would be then interesting to assess and control GABA concentrations in our conditions of culture to investigate whether it is responsible of the different responses that were observed after bicuculline treatment.

Whereas the morphological extension induced by ALLO was completely abolished by pre-treatment of the cells with bicuculline, this GABA-A antagonist did not modify the decreased phagocytic activity that was observed after the addition of ALLO. Bicuculline is considered as a competitive antagonist of GABA-A receptors, which means that it competes to occupy the GABA binding site. Bicuculline does not compete for binding at the neurosteroid sites of GABA-A receptors [68]. Unlike GABA, bicuculline cannot induce the rotation of $\beta$ subunits and, therefore, stabilizes the closed channel pore [69], with a complete blocking effect at the concentration $100 \mu \mathrm{M}$ [68]. Of prime interest, the inhibitory action of thiopental on monocyte phagocytosis was shown to only be mildly prevented by GABA-A antagonists: bicuculline and picrotoxin [70]. At the opposite, in this same study, bicuculline completely abolished the inhibitory effect of thiopental on monocyte migration [70]. These observations suggest that drugs, like anaesthetic compounds or neurosteroids, which can bind to GABA-A receptors, could also act via other mechanisms or be dependent of other factors.

Besides the mediation through GABA-A receptors, the activity of ALLO can also rely on other targets such as L-type voltage-gated calcium channels (VGCC), liver X receptors (LXRs), pregnane xenobiotic receptors (PXRs), or ATP-gated P2X receptor channels. Transcripts for L-type VGCC isoforms are detectable in immune cells [71], as well as in murine microglia [18] and BV-2 cells [72]. LXRs are members of the nuclear hormone receptor superfamily existing in two forms, the inducible LXR $\alpha$ and the ubiquitous LXR $\beta$. Both of the isoforms are expressed by $\mathrm{CD} 4^{+} \mathrm{T}$ cells and macrophages, where their activation reduces proinflammatory cytokine expression [73,74]. In BV-2 cells, the expression of LXR $\alpha$ has been associated to the anti-inflammatory activity of taraxasterol [75]. PXR is expressed in monocyte/macrophage cells, where they participate in an anti-inflammatory pathway [76]. $\mathrm{P} 2 \mathrm{X}$ receptors expression is restricted to the P2X 4 and P2 X7 receptor subtypes in microglia $[77,78]$. We can discard the reconversion of ALLO toward $5 \alpha$-dihydroprogesterone, as murine microglia seem not to express $3 \alpha$-hydroxysteroid oxydo-reductase, the enzyme that allows this reaction [79].

Steroid hormones are known to modulate cell proliferation. ALLO has also been reported to increase the proliferation of different cell types, such as postnatal hippocampal cells [37], SH-SY5Y cells [38], or Schwann cells [80]. Neither the microglial BV-2 nor the oligodendroglial $158 \mathrm{~N}$ cell line used in this study showed a modified proliferation after the administration of ALLO in the range of $10 \mathrm{nM}$ to $10 \mu \mathrm{M}$ (Figure 3C,D or Figure 6C). Accordingly, ALLO also failed to promote the proliferation of oligodendrocyte precursors in cultured cerebellar slices of seven-day-old rats [81].

The present data describe the effects of ALLO on microglial morphology and phagocytic activity. These results constitute direct evidence representing a strong and interesting starting point for further analysis to determine the underlying molecular mechanisms that lead to the observed modulatory effects on microglia in order to strengthen "neurosteroidbased approach" for the development of effective strategies against neurological disorders. Moreover, the investigations of microglial synthesis and secretion of inflammatory media- 
tors, such as cytokines and reactive oxygen species, upon ALLO treatment would represent attractive prospects.

\section{Conclusions}

To conclude, as displayed in Figure 9, we have shown that microglia express transcripts of GABA-A receptor and that they are sensitive to ALLO. In physiological condition, ALLO could represent an important molecule maintaining microglia in an inactivated state that is characterized by a ramified morphology with long and thin processes. In the pathological condition, microglia are getting activated to remove debris. An inappropriate and exacerbated activation of microglia may lead to an uncontrolled phagocytic activity of viable cells. Therefore, the restoration of normal ALLO concentrations in the CNS of MS patients deficient for this neurosteroid may prevent collateral victims and participate in the downregulation of the auto-reactive immune response that is directed against myelin.

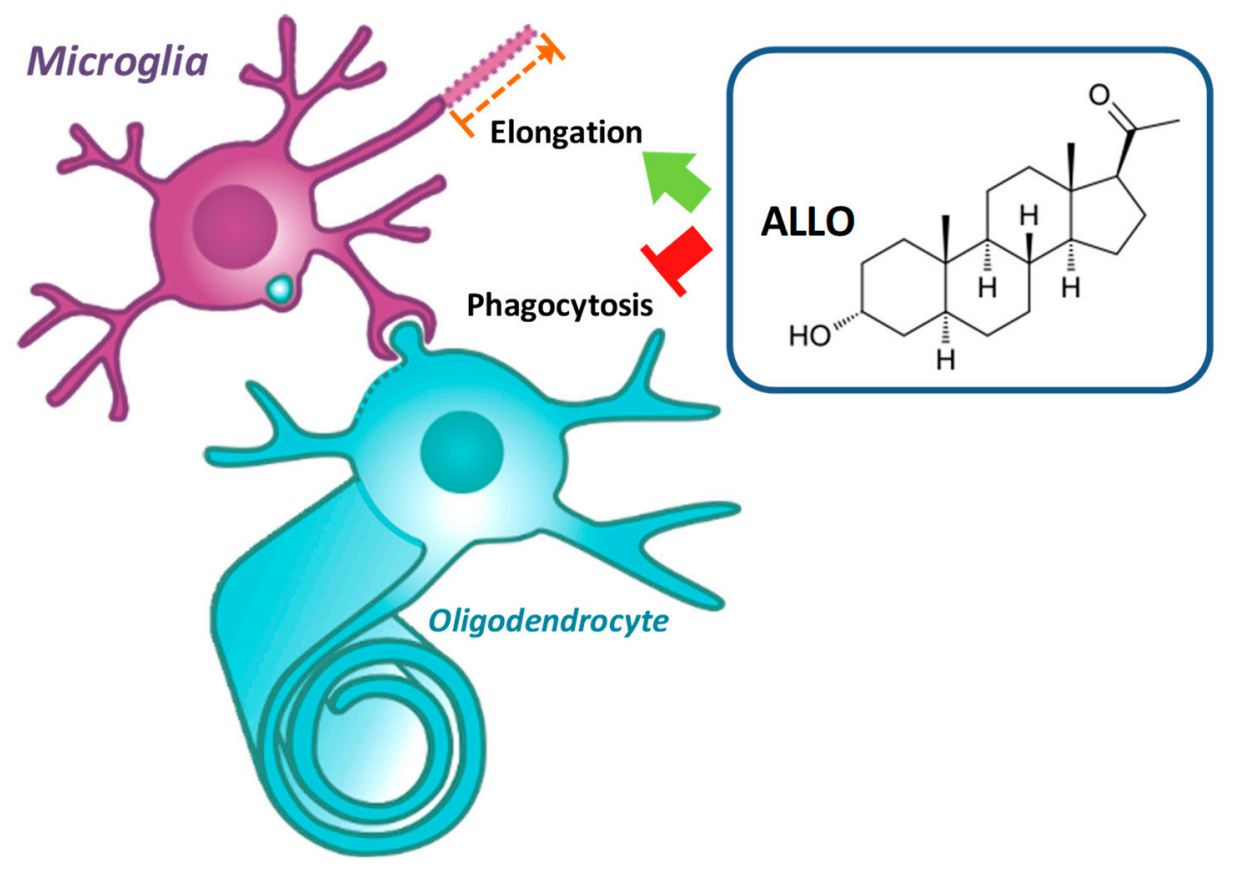

Figure 9. Graphical abstract demonstrates that the natural neurosteroid allopregnanolone (ALLO) inhibits oligodendrocyte phagocytosis by microglia. ALLO modifies also microglial morphology by increasing the length of cell processes.

Supplementary Materials: The following are available online at https:/ / www.mdpi.com/2073-440 9/10/3/698/s1, Figure S1: ALLO increases the length of BV-2 cells grown in a low concentration of serum. (A) The lengths of the processes borne by bipolar and (B) multipolar BV-2 cells were split apart., Figure S2: ALLO increases the adherence of BV-2 cells grown in a high concentration of serum. (A) BV-2 cells grown in 10\% FCS exhibited a rounded shape and seemed more adherent after incubation with ALLO $(10 \mu \mathrm{M})$. Scale bar $=10 \mu \mathrm{M}$. (B) The incubation of BV-2 cells grown in $10 \%$ FCS with ALLO increased the percentage of adherent cells (i.e., cells exhibiting processes). Mean values \pm SEM are shown, from $n=3$ independent experiments, ${ }^{*} p<0.05$., Figure S3: Purity of primary microglia culture. Flow cytometry analysis of primary microglia after CD11b and CD45 stainings.

Author Contributions: Conceptualization, V.J., C.P.-M. and A.-G.M.-N.; formal analysis, V.J., S.B., F.B., D.B., C.P.-M., A.-G.M.-N.; investigation, V.J., S.B., F.B., J.B., O.T.; resources, D.B.; writingoriginal draft preparation, V.J.; writing_review and editing, J.D.S., C.P.-M., A.-G.M.-N.; supervision, A.-G.M.-N. All authors have read and agreed to the published version of the manuscript.

Funding: This work was supported by recurring grants from Institut National de la Santé et de la Recherche Médicale (INSERM, France) and Université de Strasbourg (France).

Institutional Review Board Statement: Not applicable. 
Informed Consent Statement: Not applicable.

Data Availability Statement: The data that support the findings of this study are available from the corresponding author upon reasonable request.

Acknowledgments: The murine microglial BV-2 cell line was a generous gift of Heiko J. Luhmann (University Medical Center Johannes Gutenberg University Mainz, Institute of Physiology). We thank Sydney Lambert for her technical assistance.

Conflicts of Interest: The authors declare no conflict of interest.

\section{References}

1. Galloway, D.A.; Phillips, A.E.M.; Owen, D.R.J.; Moore, C.S. Corrigendum: Phagocytosis in the Brain: Homeostasis and Disease. Front. Immunol. 2019, 10, 790. [CrossRef] [PubMed]

2. Wang, J.; Yang, B.; Weng, Q.; He, Q. Targeting Microglia and Macrophages: A Potential Treatment Strategy for Multiple Sclerosis. Front. Pharmacol. 2019, 10, 286. [CrossRef] [PubMed]

3. Davalos, D.; Grutzendler, J.; Yang, G.; Kim, J.V.; Zuo, Y.; Jung, S.; Littman, D.R.; Dustin, M.L.; Gan, W.-B. ATP mediates rapid microglial response to local brain injury in vivo. Nat. Neurosci. 2005, 8, 752-758. [CrossRef]

4. Nimmerjahn, A.; Kirchhoff, F.; Helmchen, F. Resting Microglial Cells Are Highly Dynamic Surveillants of Brain Parenchyma in Vivo. Science 2005, 308, 1314-1318. [CrossRef]

5. Popescu, B.F.; Pirko, I.; Lucchinetti, C.F. Pathology of multiple sclerosis: Where do we stand? Continuum 2013, 19, 901-921. [CrossRef]

6. Traiffort, E.; Kassoussi, A.; Zahaf, A.; Laouarem, Y. Astrocytes and Microglia as Major Players of Myelin Production in Normal and Pathological Conditions. Front. Cell. Neurosci. 2020, 14, 79. [CrossRef]

7. Van Horssen, J.; Singh, S.; Van Der Pol, S.; Kipp, M.; Lim, J.L.; Peferoen, L.; Gerritsen, W.; Kooi, E.-J.; Witte, M.E.; Geurts, J.J.G.; et al. Clusters of activated microglia in normal-appearing white matter show signs of innate immune activation. J. Neuroinflamm. 2012, 9, 156. [CrossRef] [PubMed]

8. Singh, S.; Metz, I.; Amor, S.; Van Der Valk, P.; Stadelmann, C.; Brück, W. Microglial nodules in early multiple sclerosis white matter are associated with degenerating axons. Acta Neuropathol. 2013, 125, 595-608. [CrossRef]

9. Davalos, D.; Ryu, J.K.; Merlini, M.; Baeten, K.M.; Le Moan, N.; Petersen, M.A.; Deerinck, T.J.; Smirnoff, D.S.; Bedard, C.; Hakozaki, H.; et al. Fibrinogen-induced perivascular microglial clustering is required for the development of axonal damage in neuroinflammation. Nat. Commun. 2012, 3, 1227. [CrossRef] [PubMed]

10. Yates, R.L.; Esiri, M.M.; Palace, J.; Jacobs, B.; Perera, R.; DeLuca, G.C. Fibrin(ogen) and neurodegeneration in the progressive multiple sclerosis cortex. Ann. Neurol. 2017, 82, 259-270. [CrossRef]

11. Bohlen, C.J.; Bennett, F.C.; Tucker, A.F.; Collins, H.Y.; Mulinyawe, S.B.; Barres, B.A. Diverse Requirements for Microglial Survival, Specification, and Function Revealed by Defined-Medium Cultures. Neuron 2017, 94, 759-773. [CrossRef] [PubMed]

12. Jin, Z.; Mendu, S.K.; Birnir, B. GABA is an effective immunomodulatory molecule. Amino Acids 2011, 45, 87-94. [CrossRef] [PubMed]

13. Fontainhas, A.M.; Wang, M.; Liang, K.J.; Chen, S.; Mettu, P.; Damani, M.; Fariss, R.N.; Li, W.; Wong, W.T. Microglial Morphology and Dynamic Behavior Is Regulated by Ionotropic Glutamatergic and GABAergic Neurotransmission. PLoS ONE 2011, 6, e15973. [CrossRef]

14. Lee, M.; Schwab, C.; McGeer, P.L. Astrocytes are GABAergic cells that modulate microglial activity. Glia 2010, 59, 152-165. [CrossRef] [PubMed]

15. Paul, A.; Branton, W.; Walsh, J.; Polyak, M.; Lu, J.-Q.; Baker, G.; Power, C. GABA transport and neuroinflammation are coupled in multiple sclerosis: Regulation of the GABA transporter-2 by ganaxolone. Neuroscience 2014, 273, 24-38. [CrossRef] [PubMed]

16. Bhat, R.; Axtell, R.; Mitra, A.; Miranda, M.; Lock, C.; Tsien, R.W.; Steinman, L. Inhibitory role for GABA in autoimmune inflammation. Proc. Natl. Acad. Sci. USA 2010, 107, 2580-2585. [CrossRef]

17. Kuhn, S.A.; Van Landeghem, F.K.; Zacharias, R.; Färber, K.; Rappert, A.; Pavlovic, S.; Hoffmann, A.; Nolte, C.; Kettenmann, H. Microglia express GABA B receptors to modulate interleukin release. Mol. Cell. Neurosci. 2004, 25, 312-322. [CrossRef] [PubMed]

18. Bhandage, A.K.; Kanatani, S.; Barragan, A. Toxoplasma-Induced Hypermigration of Primary Cortical Microglia Implicates GABAergic Signaling. Front. Cell. Infect. Microbiol. 2019, 9, 73. [CrossRef]

19. Belelli, D.; Lambert, J.J. Neurosteroids: Endogenous regulators of the GABA(A) receptor. Nat. Rev. Neurosci. 2005, 6, 565-575. [CrossRef]

20. Noorbakhsh, F.; Ellestad, K.K.; Maingat, F.; Warren, K.G.; Han, M.H.; Steinman, L.; Baker, G.B.; Power, C. Impaired neurosteroid synthesis in multiple sclerosis. Brain 2011, 134, 2703-2721. [CrossRef] [PubMed]

21. Boghozian, R.; McKenzie, B.A.; Saito, L.B.; Mehta, N.; Branton, W.G.; Lu, J.; Baker, G.B.; Noorbakhsh, F.; Power, C. Suppressed oligodendrocyte steroidogenesis in multiple sclerosis: Implications for regulation of neuroinflammation. Glia 2017, 65, 1590-1606. [CrossRef] 
22. Leva, G.; Klein, C.; BenYounes, J.; Hallé, F.; Bihel, F.; Collongues, N.; De Seze, J.; Mensah-Nyagan, A.-G.; Patte-Mensah, C. The translocator protein ligand XBD173 improves clinical symptoms and neuropathological markers in the SJL/J mouse model of multiple sclerosis. Biochim. Biophys. Acta BBA Mol. Basis Dis. 2017, 1863, 3016-3027. [CrossRef]

23. Griffin, L.D.; Gong, W.; Verot, L.; Mellon, S.H. Niemann-Pick type C disease involves disrupted neurosteroidogenesis and responds to allopregnanolone. Nat. Med. 2004, 10, 704-711. [CrossRef] [PubMed]

24. Wang, J.M.; Singh, C.; Liu, L.; Irwin, R.W.; Chen, S.; Chung, E.J.; Thompson, R.F.; Brinton, R.D. Allopregnanolone reverses neurogenic and cognitive deficits in mouse model of Alzheimer's disease. Proc. Natl. Acad. Sci. USA 2010, 107, 6498-6503. [CrossRef]

25. Nezhadi, A.; Sheibani, V.; Esmaeilpour, K.; Shabani, M.; Esmaeili-Mahani, S. Neurosteroid allopregnanolone attenuates cognitive dysfunctions in 6-OHDA-induced rat model of Parkinson's disease. Behav. Brain Res. 2016, 305, 258-264. [CrossRef] [PubMed]

26. Meyer, L.; Patte-Mensah, C.; Taleb, O.; Mensah-Nyagan, A.G. Cellular and functional evidence for a protective action of neurosteroids against vincristine chemotherapy-induced painful neuropathy. Cell. Mol. Life Sci. 2010, 67, 3017-3034. [CrossRef] [PubMed]

27. Meyer, L.; Patte-Mensah, C.; Taleb, O.; Mensah-Nyagan, A.G. Allopregnanolone prevents and suppresses oxaliplatin-evoked painful neuropathy: Multi-parametric assessment and direct evidence. Pain 2011, 152, 170-181. [CrossRef] [PubMed]

28. Patte-Mensah, C.; Meyer, L.; Taleb, O.; Mensah-Nyagan, A.G. Potential role of allopregnanolone for a safe and effective therapy of neuropathic pain. Prog. Neurobiol. 2014, 113, 70-78. [CrossRef] [PubMed]

29. Taleb, O.; Bouzobra, F.; Tekin-Pala, H.; Meyer, L.; Mensah-Nyagan, A.G.; Patte-Mensah, C. Behavioral and electromyographic assessment of oxaliplatin-induced motor dysfunctions: Evidence for a therapeutic effect of allopregnanolone. Behav. Brain Res. 2017, 320, 440-449. [CrossRef]

30. Sayeed, I.; Guo, Q.; Hoffman, S.W.; Stein, D.G. Allopregnanolone, a Progesterone Metabolite, Is More Effective Than Progesterone in Reducing Cortical Infarct Volume After Transient Middle Cerebral Artery Occlusion. Ann. Emerg. Med. 2006, 47, 381-389. [CrossRef]

31. Lockhart, E.M.; Warner, D.S.; Pearlstein, R.D.; Penning, D.H.; Mehrabani, S.; Boustany, R.-M. Allopregnanolone attenuates N -methyl- $\mathrm{d}$-aspartate-induced excitotoxicity and apoptosis in the human NT2 cell line in culture. Neurosci. Lett. 2002, 328, 33-36. [CrossRef]

32. Xilouri, M.; Papazafiri, P. Anti-apoptotic effects of allopregnanolone on P19 neurons. Eur. J. Neurosci. 2006, 23, 43-54. [CrossRef] [PubMed]

33. Charalampopoulos, I.; Tsatsanis, C.; Dermitzaki, E.; Alexaki, V.-I.; Castanas, E.; Margioris, A.N.; Gravanis, A. Dehydroepiandrosterone and allopregnanolone protect sympathoadrenal medulla cells against apoptosis via antiapoptotic Bcl-2 proteins. Proc. Natl. Acad. Sci. USA 2004, 101, 8209-8214. [CrossRef] [PubMed]

34. Zampieri, S.; Mellon, S.H.; Butters, T.D.; Nevyjel, M.; Covey, D.F.; Bembi, B.; Dardis, A. Oxidative stress in NPC1 deficient cells: Protective effect of allopregnanolone. J. Cell. Mol. Med. 2009, 13, 3786-3796. [CrossRef] [PubMed]

35. Bhandage, A.K.; Jin, Z.; Korol, S.V.; Shen, Q.; Pei, Y.; Deng, Q.; Espes, D.; Carlsson, P.-O.; Kamali-Moghaddam, M.; Birnir, B. GABA Regulates Release of Inflammatory Cytokines From Peripheral Blood Mononuclear Cells and CD4+ T Cells and Is Immunosuppressive in Type 1 Diabetes. EBioMedicine 2018, 30, 283-294. [CrossRef]

36. Chu, C.; Artis, D.; Chiu, I.M. Neuro-immune Interactions in the Tissues. Immunity 2020, 52, 464-474. [CrossRef]

37. Karout, M.; Miesch, M.; Geoffroy, P.; Kraft, S.; Hofmann, H.; Mensah-Nyagan, A.; Kirsch, M. Novel analogs of allopregnanolone show improved efficiency and specificity in neuroprotection and stimulation of proliferation. J. Neurochem. 2016, 139, 782-794. [CrossRef]

38. Taleb, O.; Patte-Mensah, C.; Meyer, L.; Kemmel, V.; Geoffroy, P.; Miesch, M.; Mensah-Nyagan, A.-G. Evidence for effective structure-based neuromodulatory effects of new analogues of neurosteroid allopregnanolone. J. Neuroendocr. 2018, 30 , e12568. [CrossRef]

39. Luo, T.; Wu, J.; Kabadi, S.V.; Sabirzhanov, B.; Guanciale, K.; Hanscom, M.; Faden, J.; Cardiff, K.; Bengson, C.J.; Faden, A.I. Propofol Limits Microglial Activation after Experimental Brain Trauma through Inhibition of Nicotinamide Adenine Dinucleotide Phosphate Oxidase. Anesthesiology 2013, 119, 1370-1388. [CrossRef]

40. Binamé, F.; Sakry, D.; Dimou, L.; Jolivel, V.; Trotter, J. NG2 Regulates Directional Migration of Oligodendrocyte Precursor Cells via Rho GTPases and Polarity Complex Proteins. J. Neurosci. 2013, 33, 10858-10874. [CrossRef]

41. Müller, E.; Kerschbaum, H.H. Progesterone and its metabolites 5-dihydroprogesterone and 5-3-tetrahydroprogesterone decrease LPS-induced NO release in the murine microglial cell line, BV-2. Neuro Endocrinol. Lett. 2006, 27, 675-678.

42. Henn, A.; Lund, S.; Hedtjarn, M.; Schrattenholz, A.; Porzgen, P.; Leist, M. The suitability of BV2 cells as alternative model system for primary microglia cultures or for animal experiments examining brain inflammation. ALTEX 2009, 26, 83-94. [CrossRef]

43. Laurenzi, M.A.; Arcuri, C.; Rossi, R.; Marconi, P.; Bocchini, V. Effects of microenvironment on morphology and function of the microglial cell line BV-2. Neurochem. Res. 2001, 26, 1209-1216. [CrossRef]

44. Montilla, A.; Zabala, A.; Matute, C.; Domercq, M. Functional and Metabolic Characterization of Microglia Culture in a Defined Medium. Front. Cell. Neurosci. 2020, 14, 22. [CrossRef] [PubMed]

45. Chen, Z.; Jalabi, W.; Shpargel, K.B.; Farabaugh, K.T.; Dutta, R.; Yin, X.; Kidd, G.J.; Bergmann, C.C.; Stohlman, S.A.; Trapp, B.D. Lipopolysaccharide-Induced Microglial Activation and Neuroprotection against Experimental Brain Injury Is Independent of Hematogenous TLR4. J. Neurosci. 2012, 32, 11706-11715. [CrossRef] [PubMed] 
46. Schilling, M.; Besselmann, M.; Müller, M.; Strecker, J.K.; Ringelstein, E.B.; Kiefer, R. Predominant phagocytic activity of resident microglia over hematogenous macrophages following transient focal cerebral ischemia: An investigation using green fluorescent protein transgenic bone marrow chimeric mice. Exp. Neurol. 2005, 196, 290-297. [CrossRef] [PubMed]

47. Pinto, M.V.; Fernandes, A. Microglial Phagocytosis-Rational but Challenging Therapeutic Target in Multiple Sclerosis. Int. J. Mol. Sci. 2020, 21, 5960. [CrossRef]

48. Jolivel, V.; Bicker, F.; Binamé, F.; Ploen, R.; Keller, S.; Gollan, R.; Jurek, B.; Birkenstock, J.; Poisa-Beiro, L.; Bruttger, J.; et al. Perivascular microglia promote blood vessel disintegration in the ischemic penumbra. Acta Neuropathol. 2015, 129, 279-295. [CrossRef]

49. Heindl, S.; Gesierich, B.; Benakis, C.; Llovera, G.; Duering, M.; Liesz, A. Automated Morphological Analysis of Microglia After Stroke. Front. Cell. Neurosci. 2018, 12, 106. [CrossRef]

50. Rasmussen, S.; Wang, Y.; Kivisäkk, P.; Bronson, R.T.; Meyer, M.; Imitola, J.; Khoury, S.J. Persistent activation of microglia is associated with neuronal dysfunction of callosal projecting pathways and multiple sclerosis-like lesions in relapsing-remitting experimental autoimmune encephalomyelitis. Brain 2007, 130, 2816-2829. [CrossRef]

51. Ramaglia, V.; Hughes, T.R.; Donev, R.M.; Ruseva, M.M.; Wu, X.; Huitinga, I.; Baas, F.; Neal, J.W.; Morgan, B.P. C3-dependent mechanism of microglial priming relevant to multiple sclerosis. Proc. Natl. Acad. Sci. USA 2012, 109, 965-970. [CrossRef]

52. Carbonell, W.S.; Murase, S.-I.; Horwitz, A.F.; Mandell, J.W. Migration of Perilesional Microglia after Focal Brain Injury and Modulation by CC Chemokine Receptor 5: An In Situ Time-Lapse Confocal Imaging Study. J. Neurosci. 2005, 25, 7040-7047. [CrossRef]

53. Meyer-Luehmann, M.; Spires-Jones, T.L.; Prada, C.; Garcia-Alloza, M.; de Calignon, A.; Rozkalne, A.; Koenigsknecht-Talboo, J.; Holtzman, D.M.; Bacskai, B.J.; Hyman, B.T. Rapid appearance and local toxicity of amyloid-beta plaques in a mouse model of Alzheimer's disease. Nature 2008, 451, 720-724. [CrossRef]

54. Melfi, S.; Guevara, M.M.M.; Bonalume, V.; Ruscica, M.; Colciago, A.; Simoncini, T.; Magnaghi, V. Src and phospho-FAK kinases are activated by allopregnanolone promoting Schwann cell motility, morphology and myelination. J. Neurochem. 2017, 141, 165-178. [CrossRef]

55. Gao, Z.; Tsirka, S.E. Animal Models of MS Reveal Multiple Roles of Microglia in Disease Pathogenesis. Neurol. Res. Int. 2011, 2011, 1-9. [CrossRef] [PubMed]

56. Sieghart, W.; Savić, M.M. International Union of Basic and Clinical Pharmacology. CVI: GABAA Receptor Subtype- and Function-selective Ligands: Key Issues in Translation to Humans. Pharmacol. Rev. 2018, 70, 836-878. [CrossRef]

57. Brickley, S.G.; Mody, I. Extrasynaptic GABA(A) Receptors: Their Function in the CNS and Implications for Disease. Neuron 2012, 73, 23-34. [CrossRef] [PubMed]

58. Balan, I.; Beattie, M.C.; O’Buckley, T.K.; Aurelian, L.; Morrow, A.L. Endogenous Neurosteroid (3 $\alpha, 5 \alpha) 3$-Hydroxypregnan-20-one Inhibits Toll-like-4 Receptor Activation and Pro-inflammatory Signaling in Macrophages and Brain. Sci. Rep. 2019, 9, 1-14. [CrossRef]

59. Reddy, D.S. GABA-A Receptors Mediate Tonic Inhibition and Neurosteroid Sensitivity in the Brain. Vitam. Horm. 2018, 107, 177-191. [CrossRef] [PubMed]

60. Hosie, A.M.; Wilkins, M.E.; Da Silva, H.M.A.; Smart, T.G. Endogenous neurosteroids regulate GABAA receptors through two discrete transmembrane sites. Nat. Cell Biol. 2006, 444, 486-489. [CrossRef]

61. Chen, Z.W.; Manion, B.; Townsend, R.R.; Reichert, D.E.; Covey, D.F.; Steinbach, J.H.; Sieghart, W.; Fuchs, K.; Evers, A.S. Neurosteroid analog photolabeling of a site in the third transmembrane domain of the beta3 subunit of the GABA(A) receptor. Mol. Pharmacol. 2012, 82, 408-419. [CrossRef]

62. Lambert, J.J.; Belelli, D.; Peden, D.R.; Vardy, A.W.; Peters, J.A. Neurosteroid modulation of GABAA receptors. Prog. Neurobiol. 2003, 71, 67-80. [CrossRef] [PubMed]

63. Karababa, A.; Groos-Sahr, K.; Albrecht, U.; Keitel, V.; Shafigullina, A.; Görg, B.; Häussinger, D. Ammonia Attenuates LPS-Induced Upregulation of Pro-Inflammatory Cytokine mRNA in Co-Cultured Astrocytes and Microglia. Neurochem. Res. 2016, 42, 737-749. [CrossRef] [PubMed]

64. Callachan, H.; Cottrell, G.A.; Hather, N.Y.; Lambert, J.J.; Nooney, J.M.; Peters, J.A. Modulation of the GABAA receptor by progesterone metabolites. Proc. R. Soc. Lond. B Biol. Sci. 1987, 231, 359-369. [PubMed]

65. Puia, G.; Santi, M.; Vicini, S.; Pritchett, D.B.; Purdy, R.H.; Paul, S.M.; Seeburg, P.H.; Costa, E. Neurosteroids act on recombinant human GABAA receptors. Neuron 1990, 4, 759-765. [CrossRef]

66. Bianchi, M.T.; Macdonald, R.L. Neurosteroids shift partial agonist activation of GABA(A) receptor channels from low- to high-efficacy gating patterns. J. Neurosci. 2003, 23, 10934-10943. [CrossRef]

67. Joshi, S.; Kapur, J. Neurosteroid regulation of GABAA receptors: A role in catamenial epilepsy. Brain Res. 2019, 1703, 31-40. [CrossRef]

68. Ueno, S.; Bracamontes, J.; Zorumski, C.; Weiss, D.S.; Steinbach, J.H. Bicuculline and gabazine are allosteric inhibitors of channel opening of the GABAA receptor. J. Neurosci. 1997, 17, 625-634. [CrossRef]

69. Masiulis, S.; Desai, R.; Uchański, T.; Martin, I.S.; Laverty, D.; Karia, D.; Malinauskas, T.; Zivanov, J.; Pardon, E.; Kotecha, A.; et al. GABAA receptor signalling mechanisms revealed by structural pharmacology. Nat. Cell Biol. 2019, 565, 454-459. [CrossRef]

70. Wheeler, D.W.; Thompson, A.J.; Corletto, F.; Reckless, J.; Loke, J.C.; Lapaque, N.; Grant, A.J.; Mastroeni, P.; Grainger, D.J.; Padgett, C.L.; et al. Anaesthetic impairment of immune function is mediated via GABA(A) receptors. PLoS ONE 2011, 6, e17152. 
71. Zamponi, G.W.; Striessnig, J.; Koschak, A.; Dolphin, A.C. The Physiology, Pathology, and Pharmacology of Voltage-Gated Calcium Channels and Their Future Therapeutic Potential. Pharmacol. Rev. 2015, 67, 821-870. [CrossRef]

72. Espinosa-Parrilla, J.; Martínez-Moreno, M.; Gasull, X.; Mahy, N.; Rodríguez, M. The L-type voltage-gated calcium channel modulates microglial pro-inflammatory activity. Mol. Cell. Neurosci. 2015, 64, 104-115. [CrossRef] [PubMed]

73. Chawla, A.; Repa, J.J.; Evans, R.M.; Mangelsdorf, D.J. Nuclear Receptors and Lipid Physiology: Opening the X-Files. Science 2001, 294, 1866-1870. [CrossRef] [PubMed]

74. Walcher, D.; Kümmel, A.; Kehrle, B.; Bach, H.; Grüb, M.; Durst, R.; Hombach, V.; Marx, N. LXR Activation Reduces Proinflammatory Cytokine Expression in Human CD4-Positive Lymphocytes. Arter. Thromb. Vasc. Biol. 2006, 26, 1022-1028. [CrossRef]

75. Liu, B.; He, Z.; Wang, J.; Xin, Z.; Li, F.; Fu, Y. Taraxasterol Inhibits LPS-Induced Inflammatory Response in BV2 Microglia Cells by Activating LXRalpha. Front. Pharmacol. 2018, 9, 278. [CrossRef] [PubMed]

76. Wallace, K.; Cowie, D.E.; Konstantinou, D.K.; Hill, S.J.; Tjelle, T.E.; Axon, A.; Koruth, M.; White, S.A.; Carlsen, H.; Mann, D.A.; et al. The PXR is a drug target for chronic inflammatory liver disease. J. Steroid Biochem. Mol. Biol. 2010, 120, 137-148. [CrossRef] [PubMed]

77. Collo, G.; Neidhart, S.; Kawashima, E.; Koscovilbois, M.; North, R.A.; Buell, G. Tissue distribution of the P2X7 receptor. Neuropharmacology 1997, 36, 1277-1283. [CrossRef]

78. Tsuda, M.; Shigemoto-Mogami, Y.; Koizumi, S.; Mizokoshi, A.; Kohsaka, S.; Salter, M.W.; Inoue, K. P2X4 receptors induced in spinal microglia gate tactile allodynia after nerve injury. Nat. Cell Biol. 2003, 424, 778-783. [CrossRef]

79. Gottfried-Blackmore, A.; Sierra, A.; Jellinck, P.H.; McEwen, B.S.; Bulloch, K. Brain microglia express steroid-converting enzymes in the mouse. J. Steroid Biochem. Mol. Biol. 2008, 109, 96-107. [CrossRef]

80. Perego, C.; Di Cairano, E.S.; Ballabio, M.; Magnaghi, V. Neurosteroid allopregnanolone regulates EAAC1-mediated glutamate uptake and triggers actin changes in Schwann cells. J. Cell. Physiol. 2012, 227, 1740-1751. [CrossRef] [PubMed]

81. Ghoumari, A.M.; Baulieu, E.; Schumacher, M. Progesterone increases oligodendroglial cell proliferation in rat cerebellar slice cultures. Neuroscience 2005, 135, 47-58. [CrossRef] [PubMed] 